\title{
INTERAÇÕES SOLO, RELEVO E MATERIAL DE ORIGEM NA REGIÃO DO ALTO ESTRUTURAL DO PAU D'ALHO - SUDESTE DO BRASIL
}

\author{
Marcos Roberto PINHEIRO \\ Jéssica Rafaela COSTA
}

Beatriz Ferraz SCIGLIANO

Rosely Pacheco DIAS FERREIRA

Paola CIANFARRA

Sidneide MANFREDINI

\begin{abstract}
RESUMO
As relações solo-relevo, juntamente com as informações do material parental da cobertura pedológica, têm norteado os levantamentos de solo em todo o mundo. No Brasil, essas influências são evidentes nos mapeamentos realizados no estado de São Paulo pelo Instituto Agronômico de Campinas, produtos estes que constituem verdadeiros mapas morfopedológicos. Nesse contexto, o objetivo deste trabalho é mostrar as interações entre solo, relevo e material de origem no Alto Estrutural do Pau D'Alho (Bacia Sedimentar do Paraná), área do território paulista sustentada principalmente por arenitos, diabásios e siltitos. Para isso, foi realizado um mapeamento morfológico por fotointerpretação (1:25.000), seguido de um extenso controle de campo, onde foram conferidas as informações geomorfológicas, descritos os perfis de solo e coletadas amostras para análises granulométricas e químicas. Os resultados mostraram que predominam Neossolos Litólicos com A Chernozêmico e Cambissolos Háplicos nas vertentes mais íngremes dos morros e serras, e, nos topos destas, Latossolos Vermelhos e Nitossolos Vermelhos. Variações de solos são controladas por mudanças locais de litologia. Na zona colinosa ocorrem principalmente Argissolos Vermelho-Amarelos, Neossolos Quartzarênicos e Latossolos Vermelho-Amarelo de textura média, derivados de arenitos e siltitos. Nos fundos de vale dos canais de drenagem principais, encontram-se Gleissolos Háplicos e Neossolos Flúvicos, formados a partir de depósitos fluviais e colúvios. Embora esse cenário reflita as relações entre as formas, os materiais parentais e os solos da área, também levanta questões ainda em aberto acerca da presença de solos rasos em relevo suave, a influência da tectônica recente na cobertura pedológica, a gênese de depressões fechadas, bem como o material de origem dos Neossolos Quartzarênicos.
\end{abstract}

Palavras-chave: Relação pedogênese-morfogênese; Mapeamento geomorfológico; Levantamento de solos; Morfopedologia; Fotointerpretação.

\section{ABSTRACT}

SOIL, RELIEF AND PARENT MATERIAL INTERACTIONS IN THE PAU D'ALHO STRUCTURAL HIGH REGION, SOUTHEASTERN BRAZIL. Soil-relief relationships, together with information on parent material, have guided soil surveys all over the world. Such contributions can be seen in soil mapping carried out by the Agronomic Institute of Campinas in the State of São Paulo (Southeastern Brazil), whose products are in fact true morphopedological maps. In this context, the aim of this research is to present the interactions among soils, landforms, and parent materials 
in the Pau D'Alho Structural High located in the Paraná Sedimentary Basin in the State of São Paulo, region in which sandstones, diabase and siltstones are dominant parent materials. To reach this objective, a morphological map was prepared by means of photointerpretation (1:25,000 scale). In addition, field work was carried out to check the geomorphological information, to describe soil profiles, and to collect soil samples for grain-size and chemical analysis. The results indicate that chernozemic A Lithic and Leptic Leptosols, and Inceptisols cover the steepest slopes of ridges and hills. Ultisols and Oxisols (Kandic) occur on top of these geomorphological features. Soil variations are controlled by lithological (parent material) changes. Ultisols, Oxisols (Kandic), and Entisol Quartzipsamments predominate in the hilly landscape supported by sandstones and siltstones. Entisols Aquent and Fluvent are related to colluvial and fluvial deposits occurring in floodplains and wide open valleys of the main streams. This scenario results from the relationships among landforms, parent material, and the pedological cover in the study area. However, these results also point to open issues about the shallow soils covering very gentle surfaces, the influence of Neotectonics on soil development, the origin of closed depressions, and the parent material of the Entisol Quartzipsamments.

Keywords: Pedogenesis-morphogenesis relationship; Geomorphological mapping; Soil survey; Morphopedology; Photointerpretation.

\section{INTRODUÇÃO}

O solo é produto da interação de uma série de fatores de formação, definidos por JENNY (1941) como sendo clima, organismos, relevo, material de origem e tempo. A equação proposta por Jenny é a sistematização de questões já discutidas por DOKUCHAEV (1879), edificador da Pedologia. Contudo, outros cientistas já haviam discutido o papel de cada um desses fatores antes mesmo da existência de um ramo da ciência dedicado exclusivamente ao solo (ESPINDOLA 2014).

Ainda que todos esses fatores sejam importantes, eles assumem pesos diferentes em cada região, ou em função das escalas de abordagem. $\mathrm{O}$ próprio introdutor da Pedologia destacou a ação do clima como o mais decisivo na formação do solo em escala global, raciocínio este expresso no seu Mapa de Solos do Hemisfério Norte (DOKUCHAEV 1899), explicitando a distribuição dos solos nas grandes bandas climáticas. Alguns anos depois, seu discípulo GLINKA (1908) teve a primazia de publicar o primeiro mapa de solos do mundo, baseado naquele mapa esquemático produzido pelo mestre.

Embora o clima tenha representado um paradigma da Pedologia, outros cientistas ressaltaram outros fatores com papéis decisivos na formação do solo. HARTEMINK \& SONNEVELD (2013) e ESPINDOLA (2014) destacam que os primeiros levantamentos de solos estavam muito atrelados aos levantamentos geológicos, com forte influên- cia do substrato, como mostrado por HITCHCOCK (1838) e HILGARD (1860), nos Estados Unidos, ou RICHTOFEN (1886), na Alemanha. Essa questão é ainda mais evidente no trabalho de FALLOU (1862), que dedicou um capítulo especial aos materiais de origem na obra em que criou o termo "Pedologia".

No que tange ao relevo, destacam-se observações de Humboldt em suas viagens pela América do Sul, nos séculos XVIII e XIX, ao correlacionar as variações topográficas com mudanças no solo e na vegetação. Assim como FALLOU (1862) e DOKUCHAEV (1879), JENNY (1941) discutiu a influência do relevo enquanto fator de formação do solo, mas um grande salto em relação à importância deste fator foi dado por MILNE (1934), ao observar que os solos variam ao longo da vertente e estão articulados como os elos de uma corrente, na sua concepção de "catena". Essas observações foram fundamentais para pesquisas posteriores, como a de DELVIGNE (1965), que identificou variações mineralógicas ao longo de sequências topográficas na África Equatorial; BOCQUIER (1973) destacou o fluxo interno da água no solo como o grande responsável pelas migrações, acumulações e transformações pedológicas. Esses conhecimentos criaram as bases da Análise Estrutural da Cobertura Pedológica proposta por BOULET (1978), em que os solos compõem uma cobertura contínua que recobre as vertentes, apresentando três dimensões espaciais e uma temporal. 
A análise integrada entre formas do relevo e material de origem tem sido historicamente a base principal dos levantamentos pedológicos. Ainda que os demais fatores de formação sejam levados em conta, estes dois são facilmente mapeáveis, estando intrinsecamente ligados à cobertura pedológica. Essa relação é bastante evidente, nas quadrículas de solos levantadas pelo Instituto Agronômico de Campinas - IAC no estado de São Paulo, como nas Folhas de Marília, escala 1:100.000, ano 2000, e na da Região do Rio Ribeira de Iguape, escala 1:250.000, ano 1999, elaboradas a partir de critérios morfopedológicos.

Ainda que classicamente se considere o relevo como um fator de formação do solo, determinados estudos (DIAS FERREIRA 1997, FURQUIM 2002, VILLELA et al. 2013, VILLELA et al. 2018) revelam que o solo também influencia a formação do relevo, o que faz rever a contraposição imposta pela relação morfogênese - pedogênese, conforme colocada por TRICART (1977) e questionada por QUEIROZ NETO (2002).

No estágio atual desses conhecimentos, é plausível considerar que as formas topográficas ou de relevo e o solo evoluem de forma contínua, integrada e indissociáveis, uma vez que relevo representa a organização geométrica dos materiais em duas dimensões. Assim, mapear o solo é também representar, ainda que indiretamente, as conformações do relevo e dos materiais de origem. Nesse contexto, o objetivo deste trabalho é demonstrar como se dão as relações entre os solos, as formas de relevo e os materiais de origem na região do Alto Estrutural do Pau D'Alho, município de Piracicaba/SP, local em que as relações entre essas variáveis são bastante evidentes e constituem um exemplo didático dos processos dominantes no tropical úmido brasileiro.

\section{CARACTERIZAÇÃO DA ÁREA}

A região do Alto Estrutural do Pau D'Alho está situada na Bacia Sedimentar do Paraná (Figura 1), uma das principais unidades geotectônicas da América do Sul. Segundo MILANI (1997), esta bacia apresenta uma cobertura sedimentar que se estende do alto Ordoviciano até o Cretáceo Superior, entremeada por derrames basálticos e intrusões de rochas básicas e alcalinas. A área desta pesquisa é próxima à borda nordeste da Bacia do Paraná, na Depressão Periférica Paulista, com um relevo suave que teria se formado durante o Cenozoico, a partir da escavação da borda da bacia por grandes drenagens encaixadas em linhas estruturais (AB'SABER 1965, PINHEIRO \& QUEIROZ NETO 2014).

A Depressão Periférica apresenta relevo colinoso, cuja altitude média oscila entre 500 e $600 \mathrm{~m}$, sustentado por rochas sedimentares, especialmente arenitos, que integram o Supergrupo Tubarão (Devoniano - Carbonífero) e os grupos Passa Dois (Permiano - Triássico) e São Bento (Triássico Cretáceo) (ALMEIDA et al. 1981, PERROTTA et al. 2005). Em meio às colinas se sobressaem relevos isolados, ligeiramente mais elevados do que os do entorno, por estarem influenciados por rochas mais resistentes à erosão mecânica, como o diabásio. Dentre estes, destaca-se o do Alto Estrutural do Pau D'Alho.

A gênese dessa região está ligada não apenas à erosão diferencial, mas, principalmente, às deformações tectônicas e intrusões de diabásio, ambas ocorridas principalmente no Eo-Cretáceo (SOUSA 2002), e que deram origem a zonas elevadas em outros pontos da Depressão Periférica, como os altos estruturais de Artêmis, Pitanga, Anhembi e Jibóia (RICCOMINI 2005, MORALES 2005). As intrusões e deformações tectônicas perturbaram a estratigrafia da área, alçando as formações mais antigas, Corumbataí e Piramboia, a posições altimétricas mais elevadas do que o predominante na região (CASTRO 1973, SOUSA 2002). As falhas (NW-SE, NE-SW, E-W) são principalmente de rejeito vertical (normais e inversas), parcialmente preenchidas pelas intrusões, que também são afetadas por falhas (MORALES 2005). As reativações transcorrentes dessas falhas normais, juntamente com a presença de estruturas em coberturas cenozoicas, foram interpretadas por SOUSA (2002) como indícios de atividade neotectônica.

Essa complexa história tectono-estrutural condicionou a formação de um conjunto de serras e morros que integram o divisor de águas entre os rios Tietê e Piracicaba; chegam a atingir cerca de $745 \mathrm{~m}$ de altitude (Monte Branco) e apresentam topos convexos ou planos esculpidos em arenitos da Formação Piramboia (Triássico), além de siltitos e folhelhos arroxeados da Formação Corumbataí (Permiano). As vertentes são declivosas e apresentam muitas irregularidades (cornijas), que, em geral, coincidem com afloramentos de rocha e solos rasos (PINHEIRO 2004). Destacam-se ainda diques de diabásio no centro de parte dessas estruturas (CASTRO 1973), que eventualmente afloram nos topos, dando origem a solos mais avermelhados e argilosos, tais como Latossolos Vermelho 


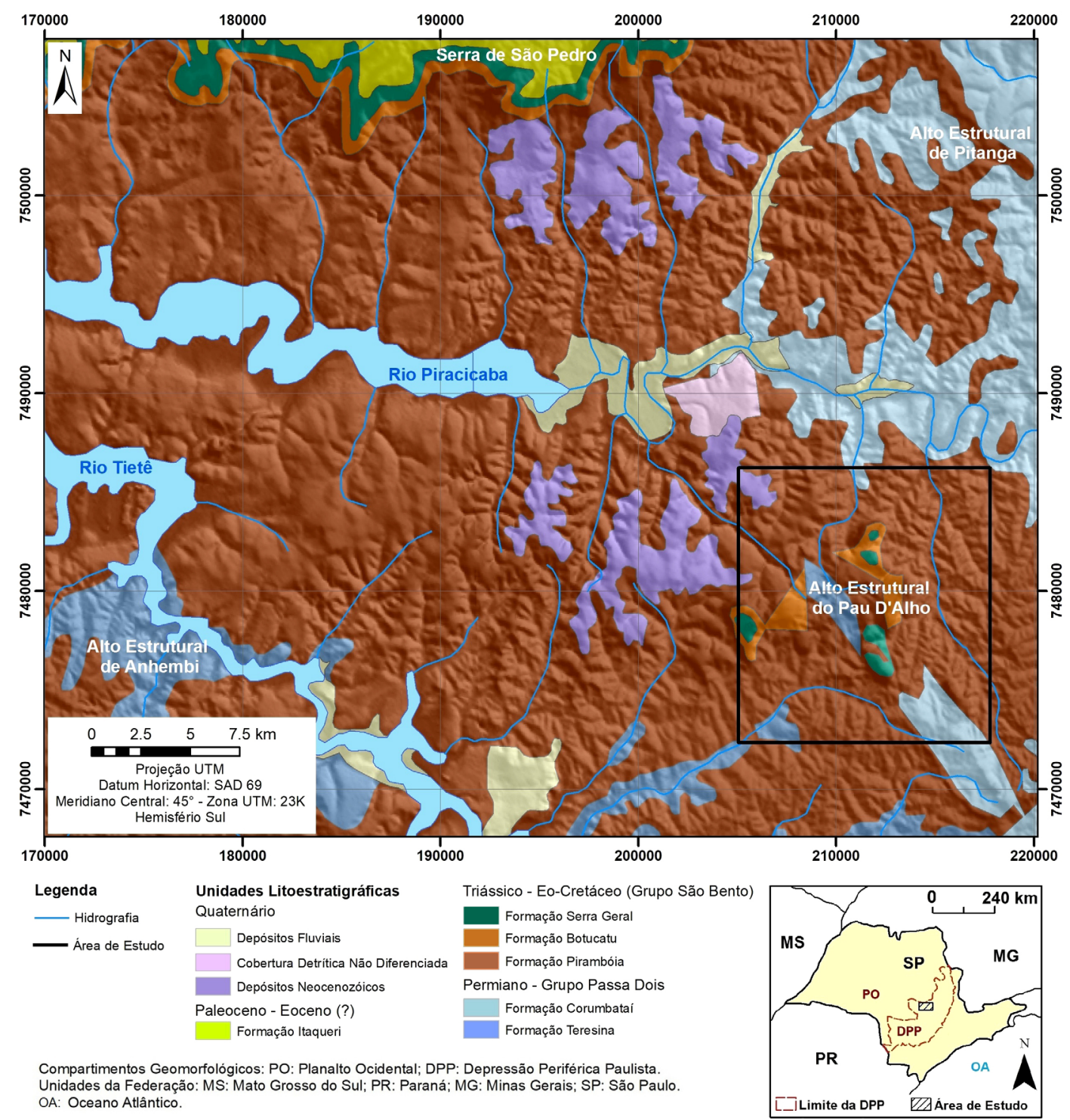

FIGURA 1 - Mapa geológico e de localização da área de estudo. Fonte: MDT: SRTM/NASA, 2000. Levantamento Geológico: PERROTTA et al. 2005.

Férrico e Nitossolos Vermelhos (OLIVEIRA \& PRADO 1989, PINHEIRO 2004).

A superfície colinosa e rebaixada no entorno das serras é sustentada por siltitos e folhelhos (Formação Corumbataí), além de arenitos finos a grossos da Formação Piramboia (Triássico), sobre as quais se formam, sobretudo, solos arenosos a areno-argilosos, como Neossolos Quartzarênicos e Litólicos, Latossolos Vermelho-Amarelo, Argissolos Vermelho-Amarelo (OLIVEIRA \& PRADO 1989, PINHEIRO 2004); nas planícies fluviais e vales de fundo chato que acompanham os principais canais de drenagem naturais que cortam a região formam- -se solos típicos de ambientes mal drenados, como Gleissolos e Neossolos Flúvicos.

\section{PROCEDIMENTOS METODOLÓGICOS}

Considerando que a cobertura pedológica é fruto de uma série de fatores de formação, este trabalho adotou uma abordagem integradora destes elementos, especialmente das informações relativas ao solo, ao relevo e ao material de origem. Nesse contexto, inicialmente foi realizada a fotointerpretação da área com fotografias aéreas pancromáticas de escala 1:25.000 (PROSPEC, ano 1962). 
Em seguida foi realizado um reconhecimento da região investigada e elaborado um mapa morfográfico (1:25.000), com a distribuição das principais formas de relevo presentes. Esse mapa, justaposto ao do levantamento geológico de CASTRO (1973), orientou a subdivisão da área em unidades morfopedológicas (CASTRO \& SALOMÃO 2000), como a primeira aproximação para o entendimento das relações entre solos, formas topográficas e material de origem.

Com base nesse mapeamento preliminar, foram realizados os primeiros trabalhos de campo para conferir os elementos representados na fotointerpretação, e verificar se as primeiras impressões acerca da distribuição dos solos se confirmavam. Essas informações nortearam os necessários aprimoramentos nos mapeamentos e determinaram quais as áreas que necessitavam de um controle de campo mais detalhado.

Nos trabalhos de campo foram feitas descrições morfológicas de perfis de solos, seguindo as recomendações de SANTOS et al. (2015), e coletadas amostras para análises laboratoriais físicas (granulometria) e químicas ( $\mathrm{pH}, \mathrm{C}$, cátions básicos, soma de bases - SB), capacidade de troca catiônica (CTC), saturação por bases (V\%) e saturação por alumínio $(\mathrm{m} \%)$. Os dados físicos foram obtidos no laboratório de Pedologia do Departamento de Geografia da Faculdade de Filosofia, Letras e Ciências Humanas da Universidade de São Paulo (DG-FFLCH-USP), seguindo protocolo de análises da instituição; as análises químicas foram realizadas na Escola Superior de Agricultura Luiz de Queiroz (ESALQ-USP).

Com respeito ao material de origem do solo inferido no campo, foi estabelecido um confronto com o mapeamento geológico de CASTRO (1973) e tomadas medidas das estruturas tectônicas por meio de bússola geológica do tipo Clar. Os dados das falhas descritas nos afloramentos, bem como as fotografias aéreas e os dados SRTM - Shuttle Radar Topography Mission, serviram de base para inferir as principais estruturas tectônicas que cortam a região.

Assim, foi elaborado o mapa da Cobertura Pedológica e Formas de Relevo da Região do Alto Estrutural do Pau D'Alho, na escala 1:25.000, e que constitui uma síntese das relações entre formas, solo e o material parental, apresentado no Anexo 1. O mapeamento das formas de relevo seguiu a proposta de QUEIROZ \& JOURNAUX (1978), aprimorada por PINHEIRO (2004) e PINHEIRO \& QUEIROZ NETO (2016). A classificação dos solos seguiu o Sistema Brasileiro de Classificação de Solos (SANTOS et al. 2018).

\section{RESULTADOS E DISCUSSÕES}

A área de estudo apresenta um modelado de relevo predominantemente suave, no qual se destacam algumas feições mais elevadas que integram o Alto Estrutural do Pau D'Alho (Anexo 1): Serra do Pau D'Alho, Serra da Floresta, Serra da Fortaleza, Monte Branco, Morro Chato e Morro do Capitão. Além destas, chamam atenção os amplos vales que acompanham os principais canais de drenagem. Essa configuração geomorfológica geral permite compartimentar a área em pelo menos três grandes domínios morfopedológicos que, embora possam ser subdivididos, apresentam características gerais comuns (Figura 2).

\subsection{Domínio 1 - Morros e Serras da Estrutura do} Pau D'Alho

Esse domínio corresponde à zona de relevo mais declivoso da área (Figura 3), sustentado por arenitos da Formação Piramboia e blocos de diabásio advindos dos topos, com vertentes de declives superiores a $12 \%$, especialmente no sopé dos morros e serras. Na meia e alta vertente, os declives são ainda maiores, acima de $30 \%$, coincidindo com o aparecimento dos paredões de rocha e planos de falha (principalmente transcorrentes e inversas) que exibem o contato entre arenitos triássicos, siltitos e folhelhos permianos, e intrusões de diabásio (Figura 4). Nos topos, essas intrusões de rochas básicas são aflorantes e condicionam um relevo com declividades menores.

Essa grande variedade geológica/geomorfológica reflete-se na cobertura pedológica: nos topos, especialmente nas serras da Floresta e Pau D'Alho, os solos são vermelhos e argilosos, porosos e de estrutura microagregrada forte ou em blocos fracamente desenvolvidos, que se desfazem em microagregrados, com profundidades que podem ultrapassar a $2 \mathrm{~m}$ (Figura 5).

Em contraposição a essa típica cobertura latossólica, a Serra da Fortaleza e o Morro Chato exibem solos mais rasos, com maior variação textural e estrutura em blocos mais desenvolvida, características comuns de Nitossolos Vermelhos Férricos. Nos pontos em que os topos são mais estreitos, como no Monte Branco e Morro do Capitão, o material de alteração é ainda mais delgado (Neossolo Litólico), muitas vezes formado apenas por um 


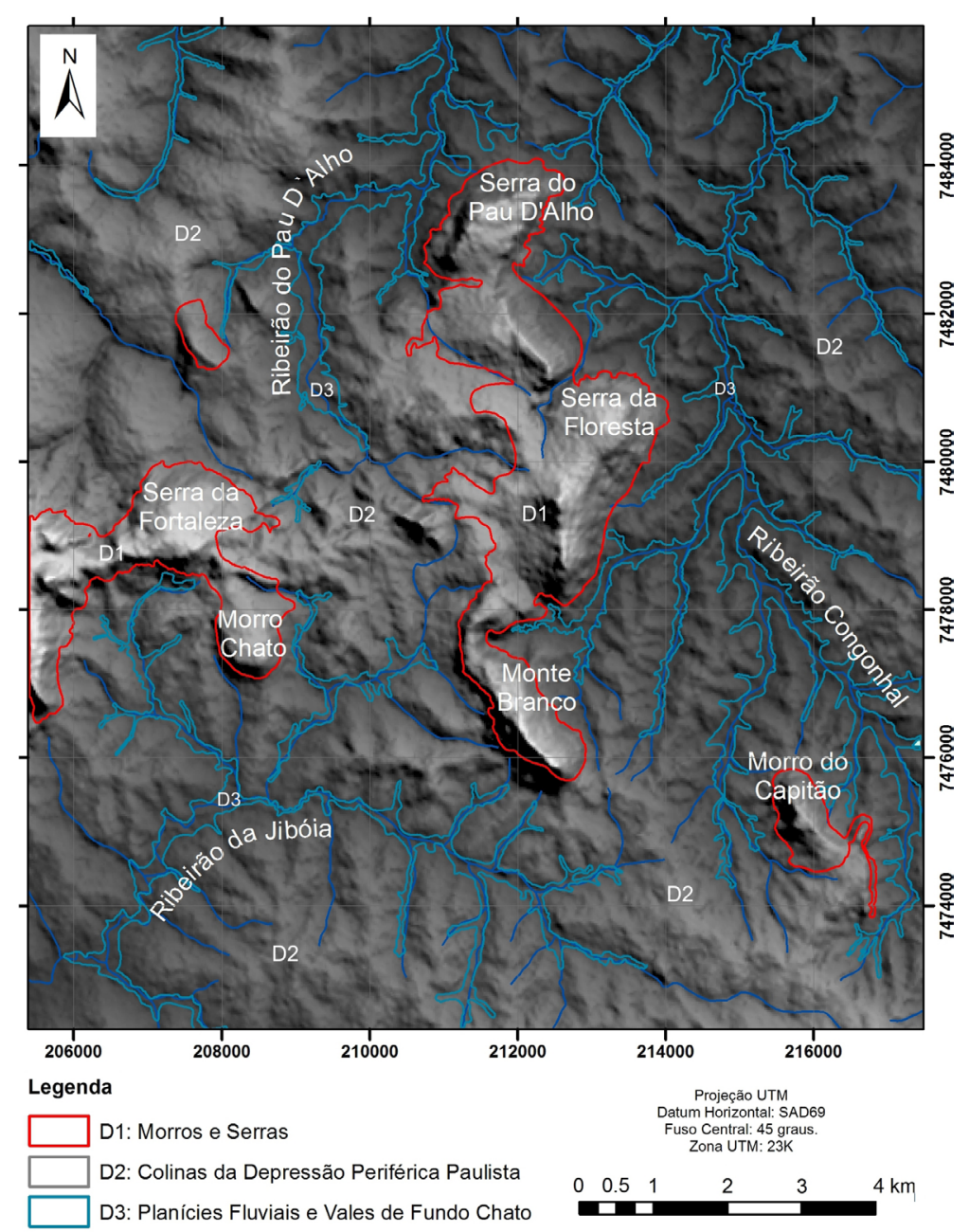

Fonte:

Modelo Digital de Terreno: SRTM/NASA, 2000. Rede de Drenagem: Folhas Topográficas do IBGE. Escala 1:50.000.

FIGURA 2 - Domínios morfopedológicos da área estudada.

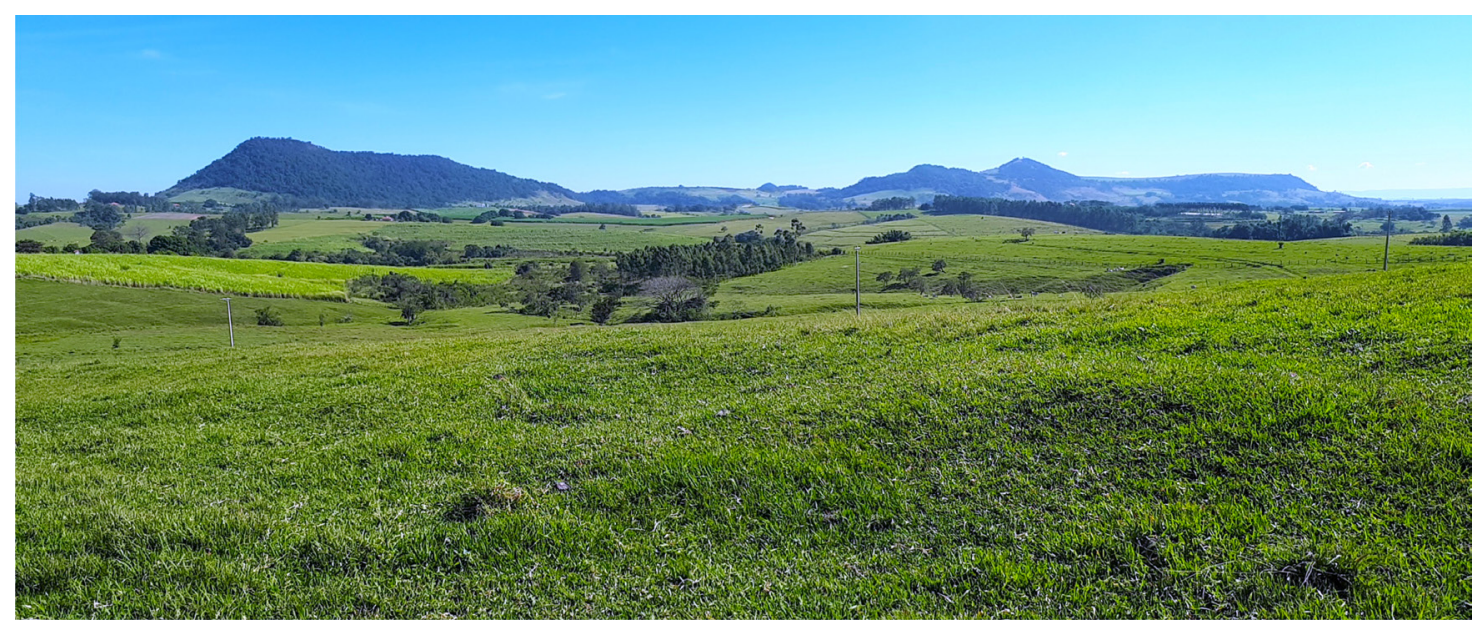

FIGURA 3 - Vista geral do Monte Branco, à esquerda, e Serra da Floresta, à direita. Em primeiro plano, relevo colinoso que integra o domínio 2 . 


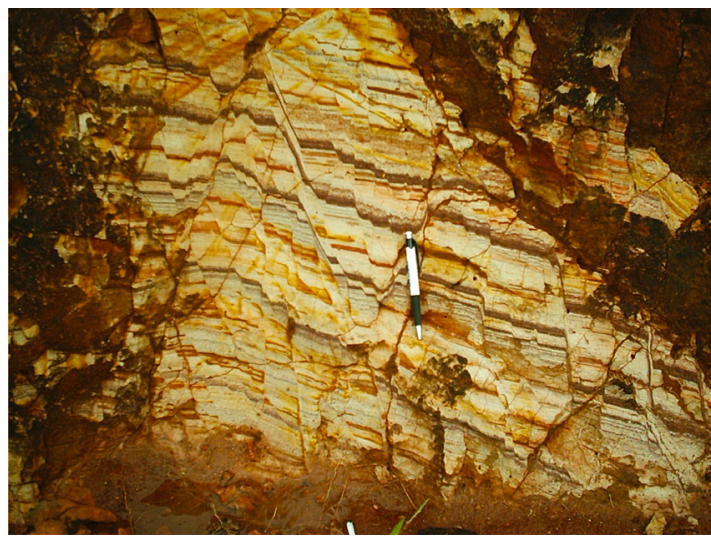

FIGURA 4 - Falhas normais e inversas em arenitos da Formação Pirambóia, em contato com intrusão de diabásio alterado. Localização: UTM 211.753E; 7.478.464N (Serra da Floresta).

horizonte A moderado ou chernozêmico argiloso, superposto à rocha pouco alterada (Figura 6).

Nas vertentes, a cobertura pedológica é mais variável, fruto não apenas das irregularidades do relevo, como da variação litológica. Nos terços médio e superior, mais íngremes, estão dispostos solos rasos, como Neossolos Litólicos (Tabelas 1, 2 e 3), e também Cambissolos, ambos argilosos e

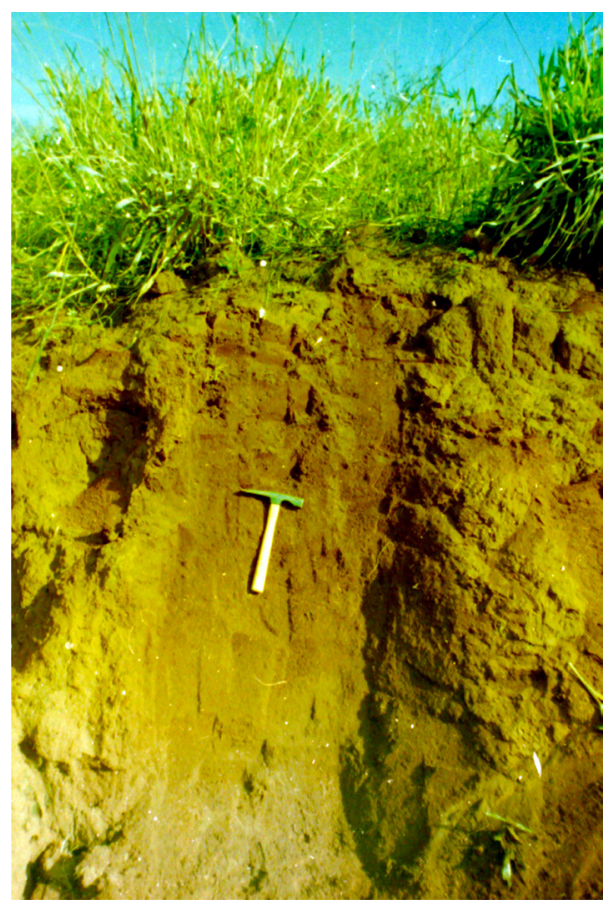

FIGURA 5 - Latossolo Vermelho Férrico na transição entre a Serra da Floresta e o Monte Branco. Localização: UTM 211.660E; 7.478.315N.

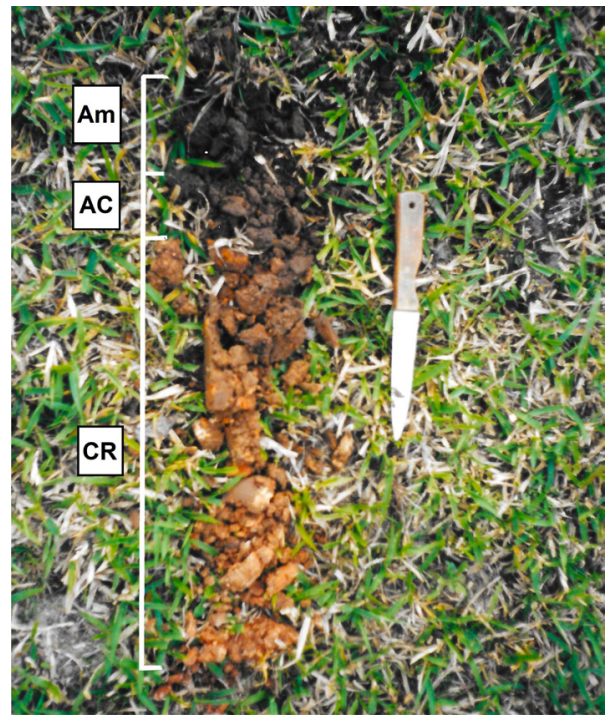

FIGURA 6 - Amostras de Neossolo Litólico com A chernozêmico coletadas com trado nas vertentes do Morro do Capitão. Localização: UTM 215.466E; 7.475.571N.

com eventuais horizontes A muito escuros (chernozêmicos), como exposto na figura 6. Além da Formação Piramboia como material de origem, há também contribuição de diabásios, arenitos e siltitos pouco alterados desde a superfície, claramente provenientes de mobilizações ao longo da vertente.

$\mathrm{Na}$ base das vertentes essa mistura de litologias é ainda mais notável, especialmente quando ocorrem cornijas, que, além de evidenciarem rupturas de declive abruptas, típicas de zonas de ocorrência de Neossolos Litólicos e afloramentos de rocha, funcionam também como patamares de condições propícias ao acúmulo de materiais.

Destaca-se ainda a ocorrência de Chernossolos (Figura 7) em áreas sustentadas pelo arenito Piramboia, o que suscita a curiosidade sobre a origem e evolução desses solos na região, uma vez que estes, cuja presença já havia sido mencionada por OLIVEIRA \& PRADO (1989) e confirmada durante os levantamentos de campo (Tabelas 1, 2 e 3), são frequentemente associados a materiais de origem cuja alteração propicia o enriquecimento de cátions básicos e acumulação de matéria orgânica.

Uma hipótese plausível para a ocorrência desses solos é a de que, embora estes estejam sobre o arenito, sua ocorrência na área estaria condicionada à presença de diabásios, eventualmente não mapeados, que costumam aflorar em topos de morros e serras. A posição topográfica singular da área de ocorrência dos Chernossolos, em patamares ou 
TABELA 1 - Descrição morfológica de Neossolo Litólico Chernossólico (RLm - Substrato arenito Piramboia), descrito em vertente íngreme do Morro do Capitão, e Chernossolo Háplico (MX - substrato arenito Piramboia e diabásio), situado em morro isolado próximo às cabeceiras do ribeirão Pau D’Alho.

\begin{tabular}{|c|c|c|c|c|c|c|c|c|}
\hline \multirow{2}{*}{$\begin{array}{l}\text { Tipo de } \\
\text { Solo }\end{array}$} & \multirow{2}{*}{$\begin{array}{l}\text { Horizonte } \\
\text { (Prof. }(\mathrm{cm})\end{array}$} & \multirow{2}{*}{$\begin{array}{l}\text { Cor Munsell } \\
\quad \text { (úmida) }\end{array}$} & \multirow{2}{*}{ Textura } & \multicolumn{3}{|c|}{ Estrutura } & \multirow{2}{*}{ Consistência Molhada } & \multirow{2}{*}{ Transição } \\
\hline & & & & Forma & Tamanho & Grau & & \\
\hline \multirow{2}{*}{$\underset{1}{\mathbb{2}}$} & $\operatorname{Am}(0-20)$ & $2,5 Y 2,5 / 1$ & $\begin{array}{l}\text { Franco } \\
\text { Arenoso }\end{array}$ & Grumos & Médio & Moderada & $\begin{array}{l}\text { Ligeiramente pegajosa e } \\
\text { ligeiramente plástica }\end{array}$ & Difusa \\
\hline & $\mathrm{CR}$ & - & - & - & - & - & - & - \\
\hline \multirow{4}{*}{ 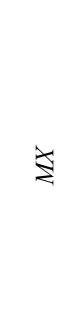 } & Am1 (0-17) & 7,5 YR $2,5 / 2$ & $\begin{array}{l}\text { Franco Argilo } \\
\text { Siltoso }\end{array}$ & Grumos & Pequena & Forte & Pegajosa e plástica & Plana e difusa \\
\hline & $\operatorname{Am} 2(17-73)$ & 7,5 YR $2,5 / 2$ & $\begin{array}{l}\text { Franco Argilo } \\
\text { Siltoso }\end{array}$ & $\begin{array}{c}\text { Blocos } \\
\text { subangulares }\end{array}$ & $\begin{array}{l}\text { Pequena a } \\
\text { média }\end{array}$ & Forte & Pegajosa e plástica & Plana e difusa \\
\hline & $\mathrm{C} 1(73-97)$ & 7,5 YR $2,5 / 2$ & $\begin{array}{l}\text { Franco Argilo } \\
\text { Siltoso } \\
\end{array}$ & $\begin{array}{c}\text { Blocos } \\
\text { angulares }\end{array}$ & Grande & Forte & Pegajosa e plástica & Plana e clara \\
\hline & C2 (97-118) & $\begin{array}{c}\text { 7,5YR 2,5/2 (matriz) e } \\
\text { 10YR 5/8 (volumes } \\
\text { milimétricos) }\end{array}$ & $\begin{array}{l}\text { Franco } \\
\text { Siltoso }\end{array}$ & $\begin{array}{l}\text { Sem estrutura } \\
\text { pedogenética }\end{array}$ & $\begin{array}{l}\text { Pegajosa e } \\
\text { plástica }\end{array}$ & - & & \\
\hline
\end{tabular}

TABELA 2 - Dados granulométricos $\left(\mathrm{g} \mathrm{Kg}^{-1}\right)$ de Neossolo Litólico Chernossólico (RLm - Substrato arenito Piramboia), descrito em vertente íngreme do Morro do Capitão, e Chernossolo Háplico (MX - substrato arenito Piramboia e diabásio), situado em morro isolado próximo às cabeceiras do ribeirão Pau D’Alho.

\begin{tabular}{ccccccccccc}
\hline Tipo de Solo & Horizonte & AMF & AF & AM & AG & AMG & AT & Silte & Argila \\
\hline \multirow{2}{*}{$R L m$} & Am & 149 & 456 & 190 & 10 & 0 & 805 & 19 & 175 \\
\cline { 2 - 10 } & $\mathrm{CR}$ & - & - & - & - & - & & - & - \\
\hline \multirow{5}{*}{$M X$} & $\mathrm{Am} 1$ & 104 & 98 & 36 & 14 & 9 & 261 & 390 & 349 \\
\cline { 2 - 10 } & $\mathrm{Am} 2$ & 129 & 128 & 44 & 12 & 4 & 317 & 373 & 311 \\
\cline { 2 - 10 } & $\mathrm{C} 1$ & 136 & 164 & 53 & 12 & 4 & 369 & 303 & 328 \\
\cline { 2 - 10 } & $\mathrm{C} 2$ & 145 & 101 & 36 & 11 & 1 & 293 & 503 & 204 \\
\hline
\end{tabular}

Legenda: AMF: areia muito fina $(0,053-0,125 \mathrm{~mm})$; AF: areia fina $(0,125-0,250 \mathrm{~mm})$; AM: areia média $(0,250-0,5 \mathrm{~mm})$; AG: areia grossa $(0,5-1 \mathrm{~mm})$; AMG: areia muito grossa $(1-2 \mathrm{~mm})$; AT: areia total.

TABELA 3 - Dados químicos de Neossolo Litólico Chernossólico (RLm - Substrato arenito Piramboia), descrito em vertente íngreme do Morro do Capitão, e Chernossolo Háplico (MX - substrato arenito Piramboia e diabásio), situado em morro isolado próximo às cabeceiras do ribeirão Pau D’Alho.

\begin{tabular}{|c|c|c|c|c|c|c|c|c|c|c|c|c|c|c|}
\hline 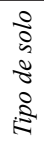 & 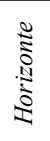 & $p H \mathrm{H}_{2} \mathrm{O}$ & $p H \mathrm{KCl}$ & $\begin{array}{c}\text { M. } O . \\
* *\end{array}$ & $\begin{array}{c}P \\
* * *\end{array}$ & $K^{*}$ & $\mathrm{Ca} *$ & $M g *$ & $A l^{*}$ & $\begin{array}{l}H+ \\
A l^{*}\end{array}$ & $S B^{*}$ & $C T C^{*}$ & $V(\%)$ & $m(\%)$ \\
\hline \multirow{2}{*}{$\underset{\mathbb{2}}{\mathbb{2}}$} & 灵 & 5,6 & 4,7 & 31 & 4 & 2,5 & 106 & 27 & 1 & 31 & 135,5 & 166,5 & 81 & 1 \\
\hline & ્ㅗ & - & - & - & - & - & - & - & - & - & - & - & - & - \\
\hline \multirow{5}{*}{ 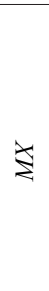 } & $\bar{\Xi}$ & 6,5 & 6,2 & 52 & 82 & 19,3 & 201 & 87 & $<0,02$ & 26 & 307,3 & 333,3 & 92 & 0 \\
\hline & 专 & 5,1 & 32 & 82 & 5,1 & 219 & 54 & 57 & $<0,02$ & 43 & 278,1 & 321,1 & 87 & 0 \\
\hline & $\bar{U}$ & 6,5 & 4,9 & 14 & 47 & 4,1 & 199 & 57 & $<0,02$ & 28 & 260,1 & 288,1 & 90 & 0 \\
\hline & U & 6,4 & 4,2 & 11 & 85 & 2,9 & 216 & 89 & 5 & 29 & 307,9 & 336,9 & 91 & 2 \\
\hline & $\tilde{U}$ & 6 & 4,7 & 9 & 9 & $<0,5$ & 15 & 2 & 1 & 10 & 17,3 & 27,3 & 63 & 5 \\
\hline
\end{tabular}

Legenda: *mmolc $\mathrm{Kg}^{-1} ; * * \mathrm{~g} \cdot \mathrm{Kg}^{-1} ; * * * \mathrm{mg} \cdot \mathrm{Kg}^{-1}$. 


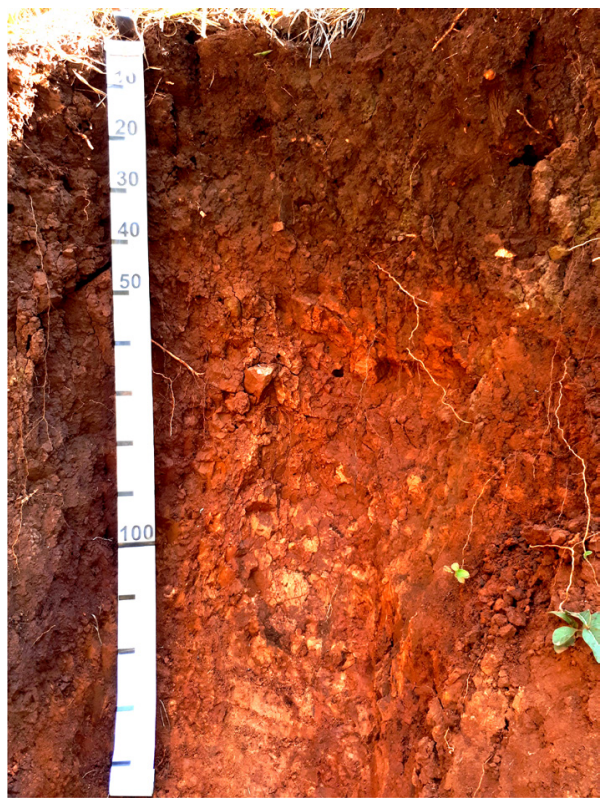

FIGURA 7 - Chernossolo desenvolvido na base de morro em cujo interior há uma intrusão de diabásio. Localização: UTM 207.724E; 7.481.636N.

na base das vertentes dos morros e serras, é favorável à receptação de fragmentos dessas rochas, e/ ou de soluções enriquecidas com produtos da sua alteração, arrastados dos topos, como o $\mathrm{Ca}^{2+} \mathrm{e} \mathrm{o}$ $\mathrm{Mg}^{2+}$ (Tabela 3); estes ficariam, em grande parte, adsorvidos na matéria orgânica dos horizontes su- perficiais, formando estruturas em blocos e grumos muito estáveis. Esse aporte de materiais tornaria o solo progressivamente mais argiloso, o que explicaria a sua textura mais fina do que a verificada em outras áreas de ocorrência dos arenitos (Tabelas 1 e 2).

Além dos Chernossolos, também chama a atenção uma ocorrência de depressão fechada (Figura 8), feição pseudocárstica típica de áreas de rochas carbonáticas, em um dos topos aplainados entre as serras do Pau D'Alho e Floresta. Essa ocorrência poderia estar relacionada a uma sustentação por rochas sedimentares e intrusões de diabásio, a exemplo das depressões dolinifomes mencionadas por CASTRO FRANÇOSO et al. (1974), no platô de Itapetininga, SP, com litologias análogas. Essa questão permanece em aberto; trabalhos mais recentes têm mostrado a ocorrência de depressões fechadas em arenitos, tanto na Depressão Periférica Paulista (PINHEIRO 2014; PINHEIRO \& QUEIROZ NETO 2016, 2017), como no reverso da cuesta (HARDT et al. 2009), atribuídas a dissoluções geoquímicas. Assim, é provável que a presente depressão também seja fruto da remoção de matérias em solução e/ou suspensão. Um fator a facilitar esse mecanismo seria uma possível maior concentração de linhas de fraturas no local, que poderiam intensificar os fluxos hídricos e suas cargas de produtos da dissolução mineral.

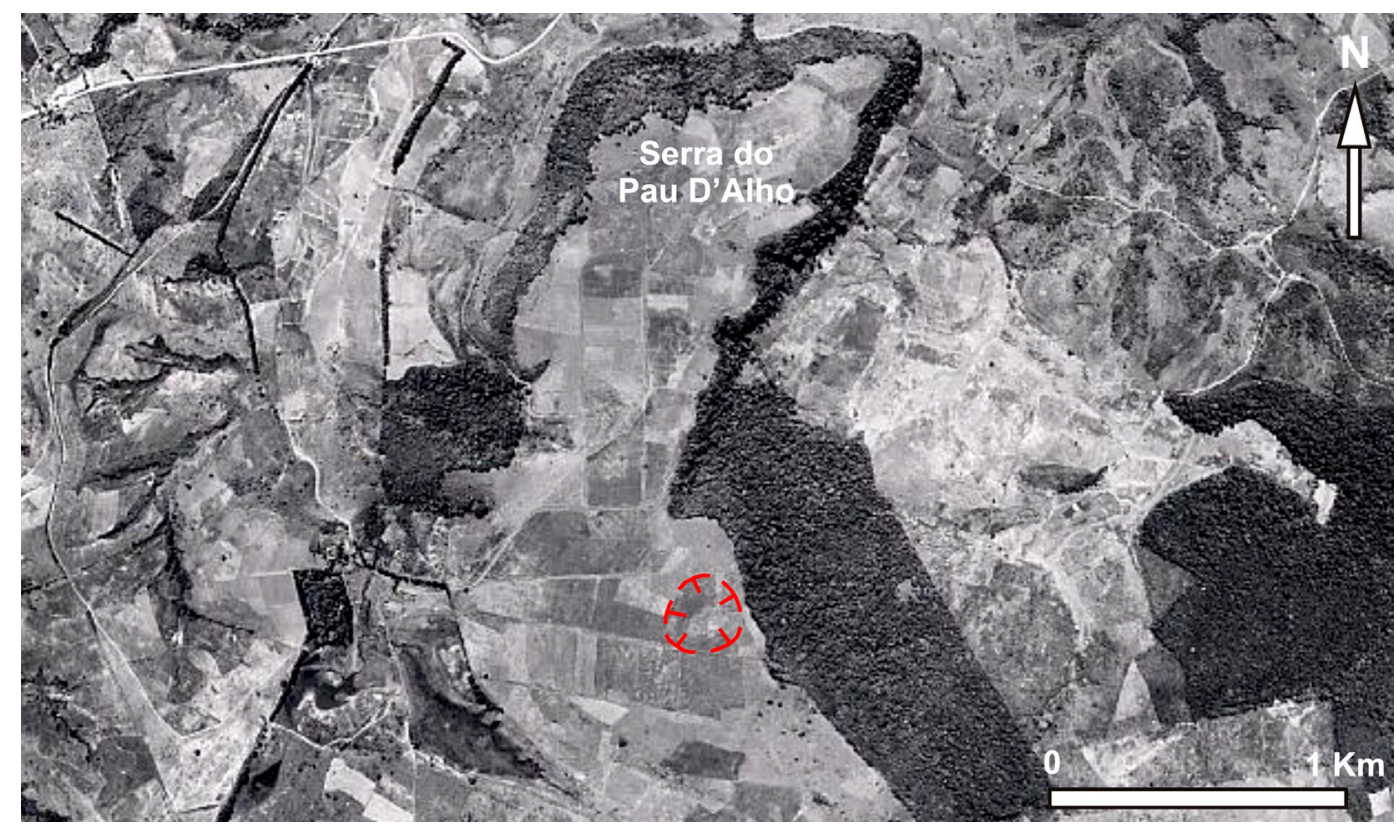

FIGURA 8 - Depressão fechada (em vermelho) entre os topos das serras do Pau D'Alho e Floresta. Fonte: Prospec S.A. Levantamento Aerofotogramétrico do Estado de São Paulo. Escala 1:25.000. Ano: 1962. 
4.2 Domínio 2 - Colinas e Morros Baixos da Depressão Periférica Paulista

Esta unidade compõe a zona de relevo mais suave (Figura 3), formada basicamente por colinas amplas e morros baixos, com topos limitados por rupturas convexas de origem fluvial. Nessas áreas de topos, as declividades geralmente não ultrapassam $12 \%$, exceto na transição para as vertentes ou na base destas, onde os valores podem chegar a $30 \%$, em virtude da maior dissecação pelo sistema fluvial. Essas formas são sustentadas principalmente por arenitos finos a grossos da Formação Piramboia, embora na porção sudeste ocorram também siltitos e folhelhos arroxeados da Formação Corumbataí.

Idealmente, essas características geológicas e geomorfológicas estariam associadas a coberturas latossólicas profundas e de textura média. Contudo, esse cenário revela variações muito maiores: os latossolos ocupam apenas os topos mais suaves das regiões central e sul da área, enquanto nos outros trechos dominam principalmente Argissolos Vermelho-Amarelos (Figura 9), especialmente em locais de declividades mais acentuadas, onde eles

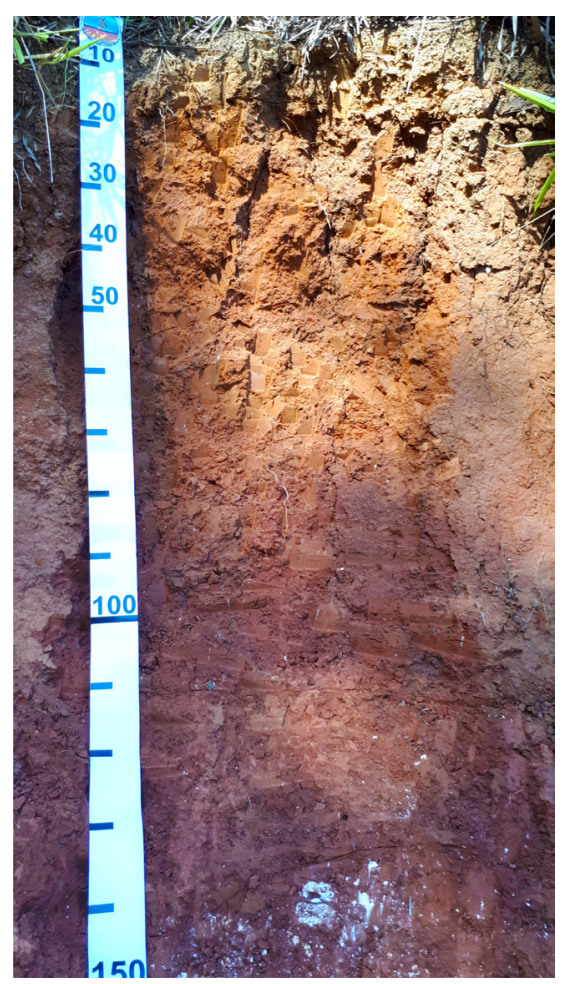

FIGURA 9 - Argissolo Vermelho-Amarelo sobre folhelhos e siltitos da Formação Corumbataí. Localização: UTM 213.686E; 7.474.400N. se associam aos solos mais rasos, Neossolos Litólicos.

Os latossolos são Vermelho-Amarelos distróficos, com A moderado e textura média, geralmente homogêneos nos atributos morfológicos (Tabela 4); são de difícil diferenciação no campo, por comparação aos Neossolos Quartzarênicos, pelas baixas quantidades de argila - pouco acima de $15 \%$ (Tabela 5). São forte a moderadamente ácidos, muito lixiviados, de baixa fertilidade natural (SB geralmente inferior a 8,3 mmolc $\mathrm{Kg}^{-1}$ - Tabela 6) e elevada suscetibilidade à erosão por escoamento difuso e/ou concentrado, especialmente nos casos em que a vegetação natural foi removida.

$\mathrm{Na}$ porção noroeste da área, com interflúvios de topos mais amplos, encontram-se solos com características semelhantes às dos Latossolos descritos na tabela 4, mas com conteúdo de argila ligeiramente menor que $150 \mathrm{~g} \mathrm{Kg}^{-1}$ (Tabela 5), abaixo do limite inferior da ordem dos Latossolos. Esses $\mathrm{Ne}$ ossolos Quartzarênicos apresentam profundidades variáveis (de $1 \mathrm{~m}$ a mais de $3 \mathrm{~m}$ ), são muito homogêneos e apresentam estrutura maciça ou em blocos fraca, que se desfaz em grãos simples (Tabela 4). Tal como os Latossolos Vermelho-Amarelos, são forte a moderadamente ácidos, pouco férteis, bastante lixiviados (Tabela 6), muito suscetíveis à erosão, e requerem manejos apropriados para serem aproveitados na agricultura.

O Mapa Geológico do Estado de São Paulo (PERROTTA et al. 2005) considerou que essas coberturas arenosas são depósitos colúvio-eluviais. Pedologicamente, esses materiais foram mapeados como Neossolos Quartzarênicos (Figura 10) nos levantamentos de OLIVEIRA \& PRADO (1989) e de PINHEIRO (2004), assim como na presente pesquisa. Essas distintas perspectivas levantam a dúvida sobre o material parental do solo: arenito Piramboia (Triássico) ou depósitos colúvio-eluviais (Pleistoceno)?

Essa questão coloca em dúvida não apenas a natureza do material de origem do solo, mas a própria evolução da cobertura pedológica associada. Caso o material seja o arenito Piramboia, é plausível supor que os Neossolos Quartzarênicos derivem de uma cobertura pedológica mais antiga, possivelmente latossólica, que, em função da progressiva perda de matéria (especialmente da fração fina), passou a conter menos de $15 \%$ de argila, ou a apresentar uma textura mais grossa do que a dos Latossolos, passando assim a compor a Ordem dos Neossolos, atingindo seu ápice de maturidade (ESPINDOLA 2010). Em se considerando ser um 
TABELA 4 - Descrições morfológicas de Latossolo Vermelho-Amarelo distrófico (LVAd - substrato arenito Pirambóia), Neossolo Quartzarênico órtico (RQo - substrato arenito Piramboia) e Argissolos Vermelho-Amarelo distrófico (PVAd - substrato arenito Piramboia e folhelhos da Formação Corumbataí).

\begin{tabular}{|c|c|c|c|c|c|c|c|c|}
\hline \multirow{2}{*}{$\begin{array}{l}\text { Tipo de } \\
\text { Solo }\end{array}$} & \multirow{2}{*}{$\begin{array}{l}\text { Horizonte/ } \\
\text { Prof. }(\mathrm{cm})\end{array}$} & \multirow{2}{*}{$\begin{array}{l}\text { Cor Munsell } \\
\text { (úmida) }\end{array}$} & \multirow{2}{*}{ Textura } & \multicolumn{3}{|c|}{ Estrutura } & \multirow{2}{*}{ Consistência Molhada } & \multirow{2}{*}{ Transição } \\
\hline & & & & Forma & Tamanho & Grau & & \\
\hline \multirow{10}{*}{ LVAd } & $0-20$ & $10 \mathrm{YR} 3 / 2$ & Areia Franca & - & - & - & Não pegajosa e não plástica & - \\
\hline & $20-40$ & $10 \mathrm{YR} 4 / 3$ & Areia Franca & - & - & - & Não pegajosa e não plástica & - \\
\hline & $40-60$ & $10 \mathrm{YR} 4 / 6$ & Areia Franca & - & - & - & Não pegajosa e ligeiramente plástica & - \\
\hline & $60-80$ & 10YR 6/8 & Areia Franca & - & - & - & Não pegajosa e ligeiramente plástica & - \\
\hline & $80-100$ & 7,5 YR $6 / 8$ & Areia Franca & - & - & - & Não pegajosa e ligeiramente plástica & - \\
\hline & $100-120$ & 7,5 YR $6 / 8$ & Areia Franca & - & - & - & Não pegajosa e ligeiramente plástica & - \\
\hline & $120-140$ & 7,5 YR $6 / 8$ & Franco Arenoso & - & - & - & Não pegajosa e ligeiramente plástica & - \\
\hline & $140-160$ & 7,5 YR $6 / 8$ & Areia Franca & - & - & - & Não pegajosa e ligeiramente plástica & - \\
\hline & $160-180$ & 7,5 YR $6 / 8$ & Areia Franca & - & - & - & Não pegajosa e ligeiramente plástica & - \\
\hline & $180-200$ & 7,5 YR $6 / 8$ & Areia Franca & - & - & - & Não pegajosa e ligeiramente plástica & - \\
\hline \multirow{4}{*}{$R Q o$} & Ap $(0-33)$ & $7,5 \mathrm{YR} 4 / 4$ & Areia Franca & Grumos & Pequena & Fraca & Não pegajosa e não plástica & Plana e difusa \\
\hline & $\mathrm{C} 1(33-87)$ & $5 Y R 4 / 6$ & Areia Franca & $\begin{array}{c}\text { Blocos } \\
\text { subangulares }\end{array}$ & Pequena & Fraca & Não pegajosa e não plástica & Plana e difusa \\
\hline & C2 (87-119) & 7,5 YR $4 / 6$ & Areia Franca & $\begin{array}{c}\text { Blocos } \\
\text { subangulares }\end{array}$ & Pequena & Fraca & Não pegajosa e não plástica & Plana e difusa \\
\hline & C3 (119-177) & $7,5 \mathrm{YR} 4 / 6$ & Areia Franca & Maciça & - & - & Não pegajosa e não plástica & - \\
\hline \multirow{6}{*}{$P V A d$} & Ap $(0-20)$ & $10 Y R 4 / 4$ & $\begin{array}{l}\text { Franco Argilo } \\
\text { Arenoso }\end{array}$ & & Apédica & & $\begin{array}{l}\text { Ligeiramente pegajosa e } \\
\text { ligeiramente plástica }\end{array}$ & Plana e clara \\
\hline & Bt1 (20-53) & $5 Y R 4 / 6$ & Franco Argiloso & & Maciça & & Plástica e pegajosa & Plana e difusa \\
\hline & Bt2 (53-78) & 2,5 YR $5 / 8$ & Franco Argiloso & $\begin{array}{c}\text { Blocos } \\
\text { subangulares }\end{array}$ & $\begin{array}{l}\text { Média a } \\
\text { grande }\end{array}$ & Forte & Plástica e pegajosa & Plana e difusa \\
\hline & Bt3 $(78-109)$ & $2,5 \mathrm{YR} 4 / 8$ & Franco Argiloso & $\begin{array}{c}\text { Blocos } \\
\text { subangulares }\end{array}$ & $\begin{array}{l}\text { Média a } \\
\text { grande }\end{array}$ & Forte & Plástica e pegajosa & Plana e difusa \\
\hline & BC (109-141) & $2,5 \mathrm{YR} 4 / 8$ & Franco Argiloso & $\begin{array}{c}\text { Blocos } \\
\text { subangulares }\end{array}$ & $\begin{array}{l}\text { Média a } \\
\text { grande }\end{array}$ & Forte & Plástica e pegajosa & Plana e difusa \\
\hline & $C(141-200)$ & $2,5 \mathrm{YR} 4 / 8$ & Franco Argiloso & $\begin{array}{c}\text { Blocos } \\
\text { subangulares }\end{array}$ & $\begin{array}{l}\text { Média a } \\
\text { grande }\end{array}$ & Forte & Plástica e pegajosa & - \\
\hline
\end{tabular}

TABELA 5 - Dados granulométricos $\left(\mathrm{g} \mathrm{Kg}^{-1}\right)$ de Latossolo Vermelho-Amarelo distrófico (LVAd - substrato arenito Piramboia), Neossolo Quartzarênico órtico (RQo - substrato arenito Piramboia) e Argissolo Vermelho-Amarelo distrófico (PVAd - substrato folhelhos da Formação Corumbataí).

\begin{tabular}{cccccccccc}
\hline $\begin{array}{c}\text { Tipo de } \\
\text { Solo }\end{array}$ & $\begin{array}{c}\text { Horizonte ou } \\
\text { Prof. }(\mathrm{cm})\end{array}$ & $A M F$ & $A F$ & $A M$ & $A G$ & $A M G$ & $A T$ & Silte & Argila \\
\hline \multirow{6}{*}{ LVAd } & $0-20$ & 323 & 429 & 109 & 2 & 0 & 864 & 66 & 70 \\
& $20-40$ & 323 & 420 & 113 & 0 & 0 & 856 & 61 & 83 \\
& $40-60$ & 280 & 414 & 142 & 1 & 0 & 836 & 61 & 102 \\
& $60-80$ & 311 & 373 & 138 & 0 & 0 & 822 & 67 & 112 \\
& $80-100$ & 304 & 363 & 128 & 2 & 1 & 797 & 83 & 120 \\
& $100-120$ & 306 & 355 & 123 & 1 & 1 & 785 & 84 & 131 \\
& $120-140$ & 316 & 340 & 137 & 1 & 0 & 793 & 57 & 150 \\
& $140-160$ & 320 & 358 & 118 & 0 & 0 & 796 & 70 & 134 \\
& $160-180$ & 328 & 358 & 111 & 1 & 0 & 798 & 71 & 131 \\
& $180-200$ & 334 & 352 & 113 & 0 & 0 & 799 & 75 & 125 \\
\hline \multirow{6}{*}{ RQo } & Ap & 124 & 368 & 324 & 60 & 5 & 881 & 56 & 63 \\
& $\mathrm{C} 1$ & 118 & 363 & 309 & 50 & 7 & 847 & 58 & 95 \\
& $\mathrm{C} 2$ & 134 & 357 & 289 & 40 & 3 & 824 & 62 & 114 \\
& $\mathrm{C} 3$ & 141 & 356 & 280 & 41 & 4 & 822 & 61 & 117 \\
\hline \multirow{6}{*}{ PVAd } & Ap & 510 & 111 & 18 & 3 & 1 & 643 & 153 & 204 \\
& $\mathrm{Bt} 1$ & 448 & 80 & 12 & 3 & 0 & 544 & 154 & 302 \\
& $\mathrm{Bt} 2$ & 449 & 80 & 11 & 3 & 1 & 543 & 150 & 307 \\
& $\mathrm{Bt} 3$ & 432 & 68 & 11 & 3 & 2 & 515 & 177 & 307 \\
& $\mathrm{BC}$ & 399 & 61 & 10 & 5 & 1 & 475 & 233 & 292 \\
& $\mathrm{C}$ & 348 & 61 & 12 & 9 & 5 & 435 & 241 & 324 \\
\hline
\end{tabular}

Legenda: AMF: areia muito fina $(0,053-0,125 \mathrm{~mm})$; AF: areia fina $(0,125-0,250 \mathrm{~mm})$; AM: areia média $(0,250-0,5 \mathrm{~mm})$; AG: areia grossa $(0,5-1 \mathrm{~mm})$; AMG: areia muito grossa $(1-2 \mathrm{~mm})$; AT: areia total. 
TABELA 6 - Dados químicos de Latossolo Vermelho-Amarelo distrófico (LVAd - substrato arenito Piramboia), Neossolo Quartzarênico órtico (RQo - substrato arenito Piramboia) e Argissolos Vermelho-Amarelo distrófico (PVAd - substrato arenito Piramboia e folhelhos da Formação Corumbataí).

\begin{tabular}{|c|c|c|c|c|c|c|c|c|c|c|c|c|c|c|}
\hline $\begin{array}{c}\text { Tipo de } \\
\text { Solo }\end{array}$ & Horizonte & $\begin{array}{c}\mathrm{pH} \\
\mathrm{H} 2 \mathrm{O}\end{array}$ & $\begin{array}{l}\mathrm{pH} \\
\mathrm{KCl}\end{array}$ & $\underset{* *}{M . O .}$ & $\underset{* * *}{P}$ & $K^{*}$ & $\mathrm{Ca}^{*}$ & $M g^{*}$ & $A l^{*}$ & $H+A l^{*}$ & $S B^{*}$ & $C T C^{*}$ & $V(\%)$ & $m(\%)$ \\
\hline \multirow{10}{*}{$\frac{\pi}{\pi}$} & $0-20$ & 5,6 & 4,5 & 11 & 7 & 0,5 & 12 & 10 & 7 & 23 & 22,5 & 45,5 & 49 & 24 \\
\hline & $20-40$ & 4,7 & 4,1 & 6 & $<2$ & $<0,5$ & 3 & 3 & 21 & 36 & 6,4 & 42,4 & 15 & 77 \\
\hline & $40-60$ & 4,5 & 4 & 10 & $<2$ & $<0,5$ & 2 & 2 & 33 & 39 & 4,4 & 43,4 & 10 & 88 \\
\hline & $60-80$ & 4,5 & 4 & 5 & $<2$ & $<0,5$ & 2 & 1 & 38 & 39 & 3,4 & 42,4 & 8 & 92 \\
\hline & $80-100$ & 4,4 & 4,1 & 4 & $<2$ & $<0,5$ & 2 & 1 & 40 & 42 & 3,4 & 45,4 & 7 & 92 \\
\hline & $100-120$ & 4,3 & 4 & 7 & $<2$ & $<0,5$ & 2 & 1 & 44 & 49 & 3,4 & 52,4 & 6 & 93 \\
\hline & $120-140$ & 4,5 & 4 & $<3,9$ & $<2$ & $<0,5$ & 4 & 2 & 36 & 39 & 6,3 & 45,3 & 14 & 85 \\
\hline & $140-160$ & 4,4 & 4 & $<3,9$ & $<2$ & $<0,5$ & 4 & 2 & 39 & 40 & 6,3 & 46,3 & 14 & 86 \\
\hline & $160-180$ & 4,5 & 4 & 8 & $<2$ & $<0,5$ & 5 & 3 & 36 & 39 & 8,3 & 47,3 & 18 & 81 \\
\hline & $180-200$ & 5,7 & 4,1 & $<3,9$ & 664 & 1,7 & 195 & 96 & 10 & 27 & 292,7 & 319,7 & 92 & 3 \\
\hline \multirow{4}{*}{$\stackrel{2}{2}$} & Ap & 5,8 & 4,6 & 7 & 9 & $<0,5$ & 15 & 1 & $<0,02$ & 14 & 16,2 & 31,2 & 52 & 0 \\
\hline & $\mathrm{C} 1$ & 5,3 & 4,2 & 6 & 6 & $<0,5$ & 8 & $<0,4$ & 8 & 21 & 8,2 & 29,2 & 28 & 49 \\
\hline & $\mathrm{C} 2$ & 5,2 & 4,2 & 5 & $<2$ & $<0,5$ & 6 & $<0,4$ & 11 & 13 & 6,2 & 19,2 & 32 & 64 \\
\hline & $\mathrm{C} 3$ & 5,4 & 4,2 & 18 & $<2$ & 3,2 & 24 & 14 & 13 & 31 & 41,2 & 72,2 & 57 & 24 \\
\hline \multirow{6}{*}{$\frac{\pi}{2}$} & Ap & 5 & 3,9 & 8 & $<2$ & 1 & 18 & 12 & 48 & 57 & 31 & 88 & 35 & 61 \\
\hline & Bt1 & 5 & 3,9 & 8 & $<2$ & 1,4 & 11 & 9 & 55 & 65 & 21,4 & 86,4 & 25 & 72 \\
\hline & Bt2 & 5,2 & 3,9 & 5 & $<2$ & 2,1 & 9 & 8 & 72 & 74 & 19,1 & 93,1 & 21 & 79 \\
\hline & Bt3 & 5,2 & 3,8 & 8 & $<2$ & 3,7 & 7 & 9 & 76 & 86 & 19,7 & 105,7 & 19 & 79 \\
\hline & $\mathrm{BC}$ & 5,1 & 3,8 & 10 & $<2$ & 4,7 & 8 & 11 & 68 & 80 & 23,7 & 103,7 & 23 & 74 \\
\hline & $\mathrm{C}$ & 6,4 & 6,1 & 14 & 81 & 0,8 & 26 & 17 & 2 & 11 & 43,8 & 54,8 & 80 & 4 \\
\hline
\end{tabular}

Legenda: *mmolc $\mathrm{Kg}^{-1} ; * * \mathrm{~g} . \mathrm{Kg}^{-1} ; * * * \mathrm{mg} . \mathrm{Kg}^{-1}$.

solo pouco desenvolvido (Neossolo), por não ter uma organização suficiente, em razão da pequena quantidade de argila para desenvolver mecanismos genéticos expressivos, isso levaria a diferenciar "solo bem desenvolvido" de "solo bem evoluído". Por outro lado, se eles decorrerem da alteração de depósitos recentes, isso implicará que a cobertura

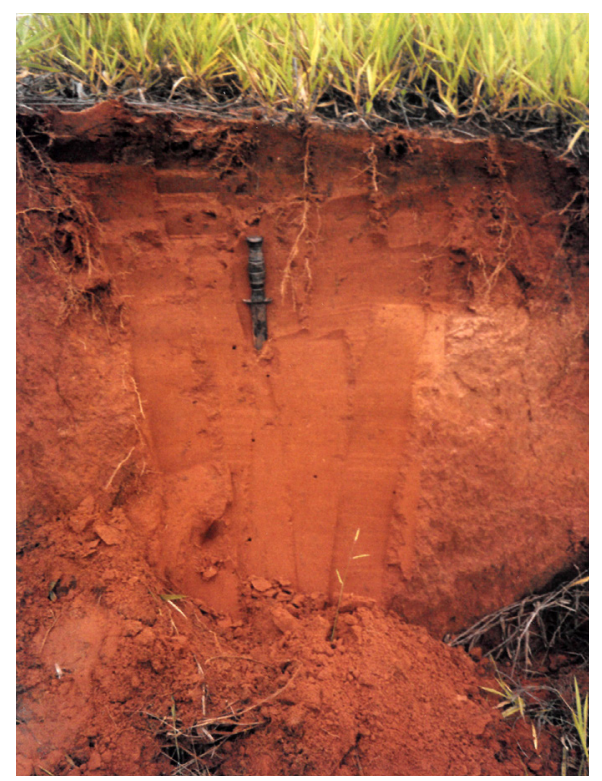

FIGURA 10 - Neossolo Quartzarênico em colinas amplas da região noroeste da área estudada. pedológica seja também jovem. Nesse caso, consistiria o início do processo de alteração em detrimento ao ápice do processo evolutivo.

Em contrapartida à homogeneidade desses Neossolos Quartzarênicos, os Argissolos de grande parte do domínio 2 apresentam variações um pouco mais expressivas. São Vermelho-Amarelos com A moderado, rasos a espessos, textura média a argilosa (Tabelas 4 e 5) e com frequente horizonte B latossólico abaixo do B textural. Quando sobre folhelhos e siltitos da Formação Corumbataí, tendem a ser mais argilosos, como assinalado por OLIVEIRA \& PRADO (1989), e avermelhados (Figura 11).

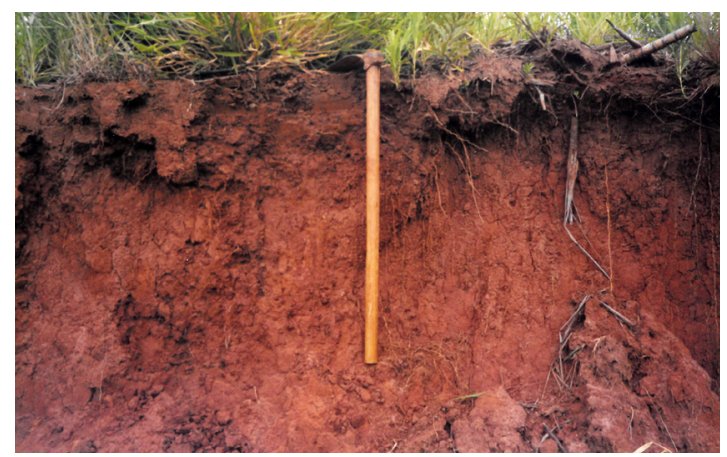

FIGURA 11 - Argissolo Vermelho desenvolvido sobre siltitos e folhelhos da Formação Corumbataí. Localização: UTM 208.735E; 7.481.906N. 
Nessas áreas colinosas recobertas por Neossolos Quartzarênicos e Argissolos ocorrem também Neossolos Litólicos, inclusive nas posições de topo (Figura 12), especialmente na zona NE da área mapeada no domínio 2, o que suscita algumas questões: (1) Teriam sido mais espessos esses solos, e atualmente mais rasos por erosões provocadas pelo aumento na dissecação fluvial em virtude de mudanças no nível de base decorrentes de atividade tectônica e/ou mudanças climáticas? (2) Seriam já rasos e assim permanecido porque nesse ponto a erosão é mais acelerada do que no entorno, impedindo o espessamento do perfil? As duas hipóteses parecem plausíveis e conduzem à ideia de que nesse local a dissecação fluvial teria sido um pouco mais expressiva que em outros pontos do domínio 2 .

Considerando que a área como um todo foi fortemente afetada pela tectônica, que provocou basculamentos de blocos e grande perturbação da estratigrafia, gerando o conjunto de morros e serras (CASTRO 1973, SOUSA 2002, MORALES 2005), é possível que a dissecação fluvial um pouco mais acentuada na área dos solos rasos, a nordeste, seja uma resposta a uma provável ascensão recente do bloco tectônico onde a zona está inserida, a exem-

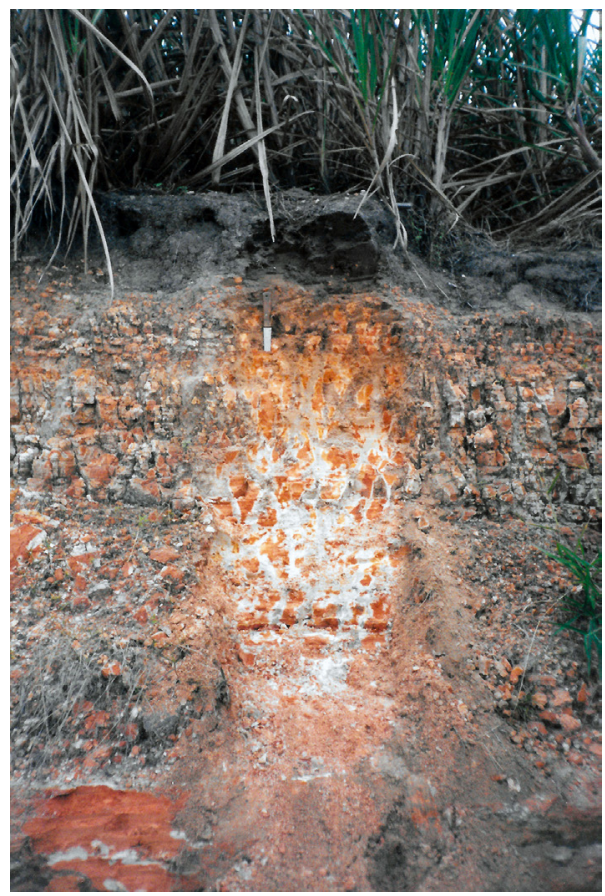

FIGURA 12 - Neossolo Litólico formado sobre arenito Piramboia, em topo de colina. Localização: UTM $215.983 \mathrm{E}, 7481.819 \mathrm{~N}$. plo de áreas próximas, como no glacis dissecado da margem direita do rio Piracicaba, em São Pedro/ SP (PINHEIRO 2014, PINHEIRO \& QUEIROZ NETO 2015). Essas questões são colocadas aqui na forma de conjecturas e reflexões, uma vez que carecem de dados que as sustentem e serão alvo de estudos futuros.

\subsection{Domínio 3 - Planícies Fluviais e Vales de Fun-} do Chato

Esta unidade abrange os vales mais amplos ao longo do canal principal e alguns tributários dos ribeirões Congonhal, da Jiboia, Pau D'Alho e Voçoroca (Figura 13), com reduzida declividade $(<3 \%)$ e materiais predominantemente arenosos, cuja origem está associada não apenas à deposição fluvial, mas também à dinâmica das vertentes (colúvios). Esses vales estão sujeitos a inundações episódicas, especialmente nas planícies, mas apresentam também porções ligeiramente mais elevadas que, provavelmente, correspondem aos níveis de terraços baixos que testemunham antigas posições do plano aluvial. Esses terraços ocorrem em porções restritas, como nos vales dos ribeirões da Jiboia e, principalmente, o Pau D'Alho; em ambos, os terraços estão em zonas com variação litológica e, de acordo com o mapa geológico da área (CASTRO 1973), ocorrência de falhas, o que suscita questões sobre um possível controle litoestrutural (neotectônico?) da formação dos terraços.

A hipótese de uma atividade tectônica recente (pós-Paleógeno) na área, influenciando no sistema fluvial, é fortalecida por uma informação levantada em campo: há uma propagação de falhas em depósitos quaternários que capeiam rochas permianas (Figura 14). Embora no exemplo da figura 14 a deformação tenha sido verificada em um interflúvio, a influência da tectônica moderna já fora apontada

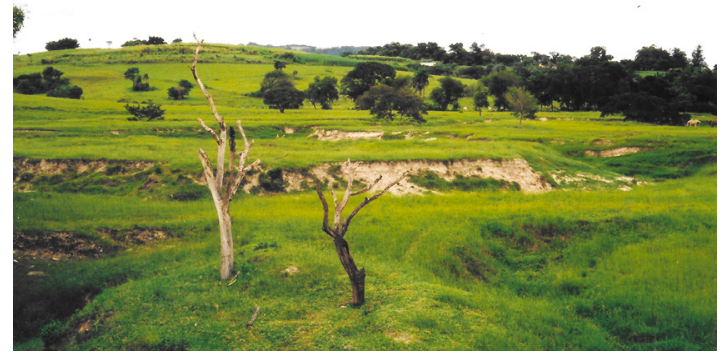

FIGURA 13 - Planície fluvial do ribeirão Congonhal. Localização: UTM 214.913E, 7.480.670N. 


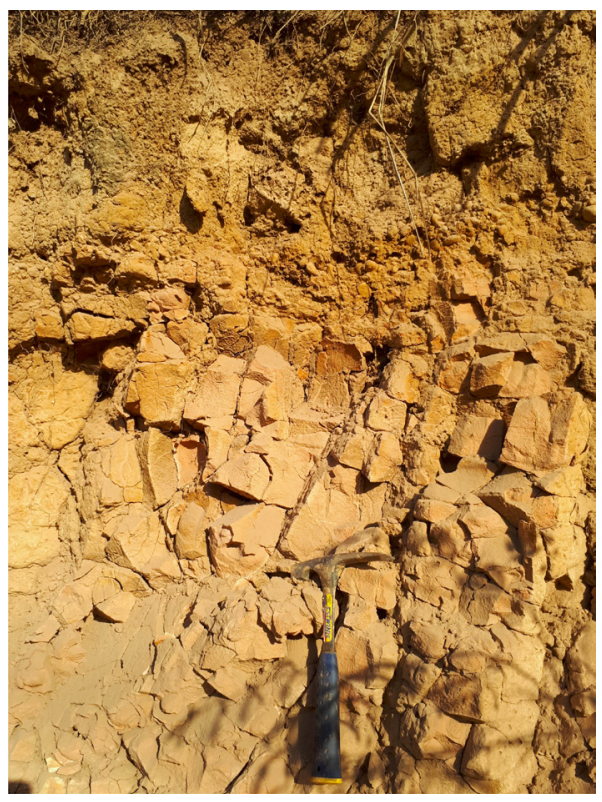

FIGURA 14 - Siltito da Formação Corumbataí capeado por sedimento quaternário (fluvial?), ambos cortados por falha inversa NW-SE. Localização: UTM 213.829E; 7.487.320N. O afloramento está próximo à área de estudo, dentro do mesmo contexto geológico/ geomorfológico/pedológico. para a área como um todo por SOUSA (2002) e MORALES (2005), ainda que ambos tenham destacado que os principais eventos tectônicos que afetaram a área teriam sido do Eo-Cretáceo. Assim, é muito improvável que essa tectônica mais intensa, mas relativamente antiga, tenha influenciado na evolução recente da cobertura pedológica. Assim, aponta-se para a necessidade da realização de mais estudos que avaliem as repercussões que a tectônica mais recente traz à cobertura pedológica local.

Nesse complexo contexto geológico-geomorfológico do domínio 3 prevalecem solos típicos de ambientes mal drenados nos níveis topográficos mais baixos, em notáveis associações a Gleissolos Háplicos eutróficos (Tabelas 7, 8 e 9, e Figura 15) e Neossolos Flúvicos e Quartzarênicos Hidromórficos, todos tendo os depósitos fluviais como material de origem fundamental. Diferentemente dos Neossolos com horizontes A moderado ou Ap sobre o substrato pouco alterado, os Gleissolos são mais desenvolvidos, com incremento de argila em profundidade e feições redoximórficas que apontam flutuações no nível freático. Estes Gleissolos são extrema a

TABELA 7 - Descrições morfológicas de Gleissolo Háplico Ta Eutrófico (GXve - substrato depósito fluvial de afluente do ribeirão do Pau D’Alho) e Argissolo Vermelho-Amarelo distrófico (PVAd - substrato depósito fluvial do ribeirão Congonhal).

\begin{tabular}{|c|c|c|c|c|c|c|c|c|}
\hline \multirow{2}{*}{$\begin{array}{l}\text { Tipo de } \\
\text { Solo } \\
\end{array}$} & \multirow{2}{*}{$\begin{array}{l}\text { Horizontel } \\
\text { Prof. }(\mathrm{cm})\end{array}$} & \multirow{2}{*}{$\begin{array}{l}\text { Cor Munsell } \\
\quad \text { (úmida) }\end{array}$} & \multirow{2}{*}{ Textura } & \multicolumn{3}{|c|}{ Estrutura } & \multirow{2}{*}{$\begin{array}{l}\text { Consistência } \\
\text { Molhada }\end{array}$} & \multirow{2}{*}{ Transição } \\
\hline & & & & Forma & Tamanho & Grau & & \\
\hline \multirow{5}{*}{ ङे } & $A p(0-22)$ & 10 YR $5 / 4$ & Areia & \multicolumn{3}{|c|}{ Apédica } & $\begin{array}{l}\text { Não pegajosa e } \\
\text { não plástica }\end{array}$ & Plana e difusa \\
\hline & $\mathrm{AC}(22-30)$ & $10 Y R 3 / 3$ & Areia Franca & Grumos & Pequena & Fraca & $\begin{array}{l}\text { Não pegajosa e } \\
\text { não plástica }\end{array}$ & Plana e difusa \\
\hline & $\operatorname{Cg} 1(30-56)$ & $\begin{array}{c}\text { 10YR } 5 / 3 \text { (matriz). } \\
\text { Volumes mosqueados } \\
\text { 10YR 4/4 (15\%) e 5YR } \\
6 / 8(5 \%)\end{array}$ & Areia Franca & $\begin{array}{c}\text { Blocos } \\
\text { subangulares }\end{array}$ & $\begin{array}{l}\text { Pequena a } \\
\text { média }\end{array}$ & Fraca & $\begin{array}{l}\text { Não pegajosa e } \\
\text { não plástica }\end{array}$ & Plana e difusa \\
\hline & $\operatorname{Cg} 2(56-82)$ & $\begin{array}{c}\text { 10YR } 3 / 2 \text {. Volumes } \\
\text { milimétricos } 2,5 \text { YR } 5 / 8 \\
\text { nos canais de raízes }\end{array}$ & Franco & $\begin{array}{c}\text { Blocos } \\
\text { subangulares }\end{array}$ & $\begin{array}{l}\text { Pequena a } \\
\text { média }\end{array}$ & Fraca & $\begin{array}{l}\text { Pegajosa e } \\
\text { plástica }\end{array}$ & Plana e difusa \\
\hline & $C(82-110)$ & $\begin{array}{c}\text { 2,5Y 7/2 (matriz). } \\
\text { Volume mosqueado } \\
\text { 7,5YR 6/8 (20\%) }\end{array}$ & Areia Franca & \multicolumn{3}{|c|}{$\begin{array}{l}\text { Sem estrutura } \\
\text { pedogenética }\end{array}$} & $\begin{array}{l}\text { Não pegajosa e } \\
\text { não plástica }\end{array}$ & - \\
\hline \multirow{7}{*}{$\frac{\pi}{2}$} & $A p(0-29)$ & $10 \mathrm{YR} 5 / 6$ & Areia Franca & $\begin{array}{c}\text { Blocos } \\
\text { subangulares }\end{array}$ & Pequena & Fraca & $\begin{array}{l}\text { Não pegajosa e } \\
\text { não plástica }\end{array}$ & Plana e difusa \\
\hline & $\mathrm{A}(29-59)$ & 10YR 5/6 & Areia Franca & $\begin{array}{c}\text { Blocos } \\
\text { subangulares }\end{array}$ & Média & Moderada & $\begin{array}{l}\text { Não pegajosa e } \\
\text { não plástica }\end{array}$ & Plana e difusa \\
\hline & $\mathrm{AE}(59-79)$ & 10YR 4/6 & Areia Franca & $\begin{array}{c}\text { Blocos } \\
\text { subangulares }\end{array}$ & Média & Forte & $\begin{array}{l}\text { Não pegajosa e } \\
\text { não plástica }\end{array}$ & Plana e difusa \\
\hline & EA(79-111) & $10 Y R 7 / 4$ & Areia Franca & $\begin{array}{c}\text { Blocos } \\
\text { subangulares }\end{array}$ & Média & Fraca & $\begin{array}{l}\text { Não pegajosa e } \\
\text { não plástica }\end{array}$ & Plana e difusa \\
\hline & Bolsão & $5 \mathrm{YR} 4 / 6$ & $\begin{array}{l}\text { Franco } \\
\text { Arenoso }\end{array}$ & $\begin{array}{c}\text { Blocos } \\
\text { subangulares }\end{array}$ & Média & Moderada & $\begin{array}{l}\text { Ligeiramente pegajosa } \\
\text { e ligeiramente plástica }\end{array}$ & Plana e difusa \\
\hline & $\mathrm{E}(111-132)$ & 10YR 5/6 & Areia Franca & $\begin{array}{c}\text { Blocos } \\
\text { subangulares }\end{array}$ & Média & Fraca & $\begin{array}{l}\text { Não pegajosa e } \\
\text { não plástica }\end{array}$ & Plana e difusa \\
\hline & $\operatorname{Bt}(132-171+)$ & $5 Y R 4 / 6$ & $\begin{array}{c}\text { Franco } \\
\text { Arenoso }\end{array}$ & $\begin{array}{c}\text { Blocos } \\
\text { subangulares }\end{array}$ & $\begin{array}{l}\text { Média a } \\
\text { grande }\end{array}$ & Forte & $\begin{array}{l}\text { Pegajosa e } \\
\text { plástica }\end{array}$ & - \\
\hline
\end{tabular}


TABELA 8 - Dados granulométricos $\left(\mathrm{g} \mathrm{Kg}^{-1}\right)$ de Gleissolo Háplico Ta Eutrófico (GXve - substrato depósito fluvial de afluente do ribeirão Pau D'Alho) e Argissolo Vermelho-Amarelo distrófico (PVAd - substrato depósito fluvial do ribeirão Congonhal).

\begin{tabular}{cccccccccc}
\hline $\begin{array}{c}\text { Tipo de } \\
\text { Solo }\end{array}$ & Horizonte & $A M F$ & $A F$ & $A M$ & $A G$ & $A M G$ & $A T$ & Silte & Argila \\
\hline \multirow{6}{*}{ GXve } & $\mathrm{Ap}$ & 562 & 325 & 50 & 1 & 0 & 938 & 57 & 5 \\
& $\mathrm{AC}$ & 573 & 287 & 33 & 2 & 1 & 897 & 76 & 27 \\
& $\mathrm{Cg} 1$ & 605 & 274 & 27 & 1 & 0 & 907 & 68 & 25 \\
& $\mathrm{Cg} 2$ & 486 & 54 & 7 & 2 & 0 & 549 & 237 & 214 \\
& $\mathrm{C}$ & 644 & 214 & 19 & 1 & 1 & 879 & 79 & 42 \\
\hline \multirow{6}{*}{ PVAd } & $\mathrm{Ap}$ & 317 & 430 & 104 & 7 & 1 & 859 & 85 & 56 \\
& $\mathrm{~A}$ & 308 & 460 & 106 & 6 & 0 & 879 & 73 & 47 \\
& $\mathrm{AE}$ & 317 & 464 & 106 & 6 & 1 & 895 & 73 & 32 \\
& $\mathrm{EA}$ & 328 & 468 & 106 & 6 & 1 & 909 & 77 & 14 \\
& $\mathrm{Bolsão}$ & 293 & 414 & 95 & 6 & 2 & 810 & 91 & 99 \\
& $\mathrm{E}$ & 324 & 427 & 104 & 6 & 0 & 861 & 81 & 58 \\
& $\mathrm{Bt}$ & 291 & 359 & 86 & 5 & 1 & 743 & 92 & 165 \\
\hline
\end{tabular}

Legenda: AMF: areia muito fina $(0,053-0,125 \mathrm{~mm})$; AF: areia fina $(0,125-0,250 \mathrm{~mm})$; AM: areia média $(0,250-0,5 \mathrm{~mm})$; AG: areia grossa $(0,5-1 \mathrm{~mm})$; AMG: areia muito grossa $(1-2 \mathrm{~mm})$; AT: areia total.

TABELA 9 - Dados químicos de Gleissolo Háplico Ta Eutrófico (GXve - substrato depósito fluvial de afluente do ribeirão Pau D'Alho) e Argissolo Vermelho-Amarelo distrófico (PVAd - substrato depósito fluvial do ribeirão Congonhal).

\begin{tabular}{|c|c|c|c|c|c|c|c|c|c|c|c|c|c|c|}
\hline $\begin{array}{c}\text { Tipo de } \\
\text { Solo }\end{array}$ & Horizonte & $\begin{array}{c}p H \\
H 2 O\end{array}$ & $\begin{array}{l}p H \\
K C l\end{array}$ & $\underset{* *}{M .} O$. & $\underset{* * *}{P}$ & $\begin{array}{l}K \\
*\end{array}$ & $\begin{array}{c}\mathrm{Ca} \\
*\end{array}$ & $\underset{*}{M g}$ & $\begin{array}{c}A l \\
*\end{array}$ & $\begin{array}{c}H+A l \\
\quad *\end{array}$ & $\begin{array}{c}S B \\
*\end{array}$ & $\begin{array}{c}C T C \\
*\end{array}$ & $\begin{array}{c}V \\
(\%)\end{array}$ & $\begin{array}{c}m \\
(\%)\end{array}$ \\
\hline \multirow{5}{*}{ 気 } & Ap & 5,6 & 4,4 & 6 & 18 & 0,6 & 9 & 5 & $<0,02$ & 13 & 14,6 & 27,6 & 53 & 0 \\
\hline & $\mathrm{AC}$ & 5,3 & 4,3 & 14 & 9 & 0,5 & 17 & 6 & 1 & 19 & 23,5 & 42,5 & 55 & 4 \\
\hline & $\mathrm{Cg} 1$ & 5,2 & 4,2 & 7 & 6 & $<0,5$ & 13 & 4 & 3 & 14 & 17,3 & 31,3 & 55 & 15 \\
\hline & $\mathrm{Cg} 2$ & 5,7 & 4,6 & 19 & 3 & 1 & 83 & 38 & 1 & 31 & 122 & 153 & 80 & 1 \\
\hline & $\mathrm{C}$ & 6,1 & 4,6 & 7 & 6 & $<0,5$ & 24 & 9 & $<0,02$ & 7 & 33,4 & 40,4 & 83 & 0 \\
\hline \multirow{7}{*}{$\frac{\pi}{R}$} & Ap & 5 & 4,1 & 7 & 4 & 0,5 & 9 & 2 & 7 & 21 & 11,5 & 32,5 & 35 & 38 \\
\hline & A & 5 & 4,1 & 10 & $<2$ & $<0,5$ & 7 & 1 & 9 & 17 & 8,3 & 25,3 & 33 & 52 \\
\hline & $\mathrm{AE}$ & 5 & 4,1 & 6 & $<2$ & $<0,5$ & 5 & 1 & 6 & 14 & 6,3 & 20,3 & 31 & 49 \\
\hline & EA & 5,1 & 4,2 & 6 & $<2$ & $<0,5$ & 4 & $<0,4$ & 3 & 10 & 4,2 & 14,2 & 30 & 42 \\
\hline & Bolsão & 4,7 & 4 & 4 & $<2$ & $<0,5$ & 7 & 1 & 10 & 23 & 8,3 & 31,3 & 27 & 55 \\
\hline & E & 5,1 & 4 & 7 & $<2$ & $<0,5$ & 6 & 1 & 10 & 18 & 7,4 & 25,4 & 29 & 57 \\
\hline & $\mathrm{Bt}$ & 4,9 & 3,8 & 5 & $<2$ & 0,5 & 13 & 3 & 23 & 34 & 16,5 & 50,5 & 33 & 58 \\
\hline
\end{tabular}

Legenda: *mmolc $\mathrm{Kg}^{-1} ; * * \mathrm{~g} . \mathrm{Kg}^{-1} ; * * * \mathrm{mg} \cdot \mathrm{Kg}^{-1}$.

fortemente ácidos, e podem apresentar horizontes minerais subsuperficiais com acumulações de matéria orgânica, evidenciadas pelas cores ligeiramente mais escuras (10YR 3/2) e pela quantidade um pouco mais elevada de carbono orgânico - entre 14 e $19 \mathrm{~g} \mathrm{Kg}^{-1}$ (Tabela 9). Nos terraços são também encontrados Gleissolos Háplicos em associação com Cambissolos Háplicos, ambos de alterações de depósitos fluviais e coluviais.

Nos terraços mais elevados, fora do atual plano aluvial, podem se formar eventuais Argissolos Vermelho-Amarelos com bandas ondula- das (Tabelas 7, 8 e 9 e Figura 16). O claro contraste de cor entre os horizontes eluviais (10YR 4/6 a 10YR 5/6) e iluviais (5YR 4/6) é acompanhado de uma mudança textural abrupta $(2,83)$, mas a quantidade de argila é relativamente baixa, próxima de $160 \mathrm{~g} \mathrm{Kg}^{-1}$, tal como nos Latossolos dos topos das colinas do domínio 2. São muito lixiviados, à exceção do horizonte $\mathrm{B}$ textural, que, além de apresentar concentração de bases um pouco mais elevada do que os horizontes sobrejacentes (Tabela 9), deve conter maior quantidade de óxidos de ferro, dada a cor mais avermelhada dos constituintes que o integram. 


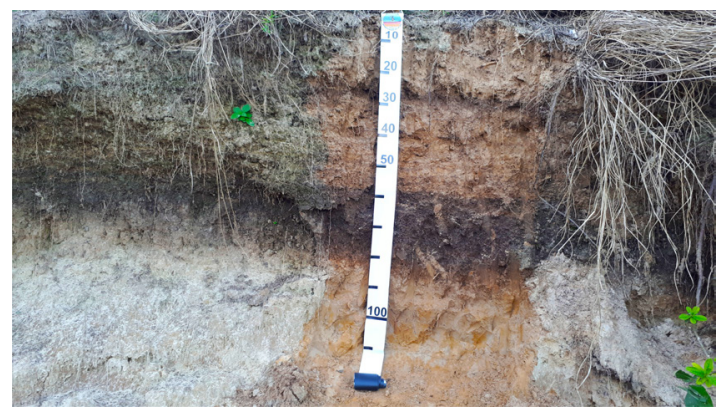

FIGURA 15 - Gleissolo com horizontes de acumulação de matéria orgânica, na planície do ribeirão Congonhal. Localização: UTM 214.937E; 7.480.652N.

\section{CONSIDERAÇÕES FINAIS}

A região do Alto Estrutural do Pau D'Alho apresenta uma configuração geomorfológica bastante complexa, fortemente influenciada pela tectônica distensiva do Eo-Cretáceo e pelas reativações transcorrentes atribuídas ao regime neotectônico, como discutido na literatura. Esse controle estrutural sobre as formas, juntamente com as variações litológicas presentes na área, resulta num modelado de relevo bastante diverso, o que se reflete numa cobertura pedológica bastante heterogênea.

De forma geral, predominam Argissolos Vermelho-Amarelos, Neossolos Quartzarênicos e Latossolos Vermelho Amarelo de textura média na zona mais colinosa (Domínio 2), Neossolos Litólicos com A Chernozêmico e Cambissolos Háplicos nas vertentes mais íngremes dos morros e serras, e, nos topos destas, Latossolos Vermelhos e Nitossolos Vermelhos (Domínio 1). Contudo, esse aspecto geral é entremeado por inúmeras variações locais, condicionadas especialmente pelas variações litológicas, que dão origem a solos de ocorrência restrita, formados a partir de mais de um material de origem, como os Chernossolos. Nos fundos de vale dos canais de drenagem principais, encontram-se solos típicos de ambientes mal drenados, especialmente Gleissolos e Neossolos Flúvicos, ambos formados a partir de depósitos fluviais e colúvios.

O cenário morfopedológico mostrado esclarece, de forma geral, como se dão as relações entre as formas, o material parental e a cobertura pedológica presente. Contudo, muitas questões permanecem em aberto, como a presença de solos rasos em áreas de relevo suave, a influência da tectônica recente na cobertura pedológica, a gênese de uma depressão fechada no topo da Serra da Floresta e o material de origem dos Neossolos Quartzarênicos. Essas problemáticas merecem ser alvo de estudos futuros.

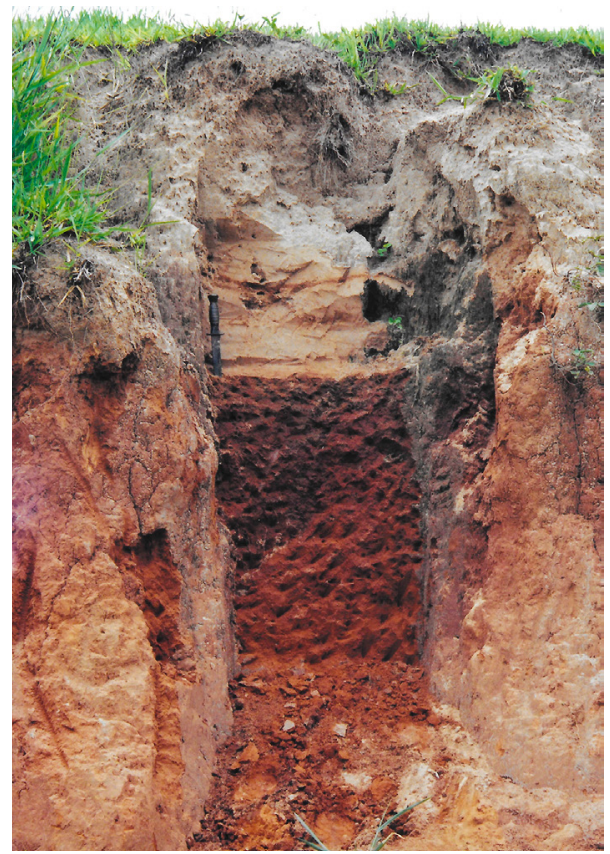

FIGURA 16 - Argissolo Vermelho-Amarelo com bandas onduladas, situado em terraço fluvial junto a afluente do ribeirão do Pau D'Alho. Localização UTM 209.493E; 7.483.237N.

\section{AGRADECIMENTOS}

Os autores agradecem os relatores da Revista do Instituto Geológico pelas sugestões que enriqueceram o trabalho.

\section{REFERÊNCIAS BIBLIOGRÁFICAS}

AB'SÁBER, A.N. 1965. Da participação das depressões periféricas e superficies aplainadas na compartimentação do Planalto Brasileiro. Faculdade de Filosofia, Ciências e Letras, Universidade de São Paulo, São Paulo, Tese de Livre-Docência, 180 p.

ALMEIDA, F.F.M.; HASUI, Y.; PONÇANO, W.L.; DANTAS, A.S.L.; CARNEIRO, C.D.R.; MELO, M.S.; BISTRICHI, C.A. 1981. Mapa Geológico do Estado de São Paulo (escala 1:500.000). Instituto de Pesquisas Tecnológicas, São Paulo, 126 p. e mapa.

BOCQUIER, G. 1973. Génèse et évolution de deux toposéquences de sols tropicaux du Tchad: intérpretation biogéodynamique. Paris: ORSTOM, 351 p. (Mémoires ORSTOM, 62). 
BOULET, R. 1978. Toposéquences de sols tropicaux en Haute-Volta: équilibres et deséquilibres pédobioclimatiques. Paris: ORSTOM, 272 p. (Mémoires ORSTOM, 85).

CASTRO, P.R.M. 1973. Contribuição ao estudo da estrutura do Pau d'Alho (Piracicaba, $S P)$. Faculdade de Engenharia de Limeira, Universidade de Campinas, Campinas, Tese de Doutorado, $87 \mathrm{p}$.

CASTRO, S.S.; SALOMÃO, F.X.T. 2000. Compartimentação morfopedológica e sua aplicação: considerações metodológicas. Geousp, 7: 27-36. https://doi.org/10.11606/ issn.2179-0892.geousp.2000.123401

CASTRO FRANÇOSO, S.; AILlAUD, C.; QUEIROZ NETO, J.P. 1974. Depressões doliniformes do Platô de Itapetininga, SP: tentativa de interpretação. In: SBG, CONGRESSO BRASILEIRO DE GEOLOGIA, 28, Porto Alegre, Anais, 3: 8590 .

DELVIGNE, J. 1965. Pédogenèse en zone tropicale. La formation des minéraux secondaires en milieu ferralitique. Paris: ORSTOM, 117 p. (Mémoires ORSTOM, 13).

DIAS FERREIRA, R.P. 1997. Solos e Morfogênese em São Pedro. Departamento de Geografia, Faculdade de Filosofia, Letras e Ciências Humanas, Universidade de São Paulo, São Paulo, Tese de Doutorado, 157 p.

DOKUCHAEV, V.V. 1879. Short description and crytical analysis of the more important soil classifications. Trav. Soc. Nat. St. Petersburg, 10: 64-67 (Translation into English by the Soil Science Society of America - Soil Science Bibliography). Disponível em http:// www.soils.org/. Acessado em 29 ago. 2014.

DOKUCHAEV, B., 1899. Zones des sols de l'hémisphère septentrional. Manuscript, St. Petersbourg.

ESPINDOLA, C.R. 2010. Descompassos entre a geomorfologia e a pedologia no estudo da evolução da paisagem. In: UGB, SIMPÓSIO NACIONAL DE GEOMORFOLOGIA, 7, Recife, Palestra, CD-Rom.

ESPINDOLA, C.R. 2014. A institucionalização da Pedologia como ciência por Friedrich
Albert Fallou - o caso brasileiro. Revista do Instituto Geológico, 35(1): 61-70. http:// dx.doi.org/10.5935/0100-929X.20140005

FALLOU, F.A. 1862. Pedologie oder allgemeine und besondere Bodenkunde. G. Schönfeld's Buchlandlung, Dresden, 487 p. ("Pedologia ou Ciência do Solo geral e especial").

FURQUIM, S.A.C. 2002. Interações entre modelado e solo no transecto Espraiado, São Pedro, SP. Departamento de Geografia, Faculdade de Filosofia, Letras e Ciências Humanas, Universidade de São Paulo, São Paulo, Dissertação de Mestrado, 146 p. https://dx.doi.org/10.11606/D.8.2002.tde01082005-105035

GLINKA, K.D. 1908. Soil Science. A.F. Devrien Publishing House, St. Petersburg, 568 p. 32 Figures and a Soil Map of the Globe [In Russian].

HARDT, R.; RODET, J.; PINTO, S.A.F.; WILLEMS, L. 2009. Exemplos brasileiros de carste em arenito: Chapada dos Guimarães (MT) e Serra de Itaqueri (SP). Espeleo-Tema, 20(1/2): 7-23.

HARTEMINK, A.E.; SONNEVELD, M.P.W. 2013. Soil maps of the Netherlands. Geoderma, 204-205: 1-9. https://doi.org/10.1016/j. geoderma.2013.03.022

HILGARD, E.W. 1860. Report on the geology and agriculure on the State of Mississipi. E. Banksdale State Printer, Jackson, 391 p.

HITCHCOCK, E. 1838. Re-examination of the economical geology of Massachussets. Dutton and Wentworth, State Printers, Boston, $139 \mathrm{p}$.

JENNY, H. 1941. Factors of soil formation, a system of quantitative pedology. McGrawHill, New York, 281 p.

MILANI, E.J. 1997. Evolução tectonoestratigráfica da Bacia do Paraná e seu relacionamento com a geodinâmica fanerozoica do Gondwana Sul-Ocidental. Instituto de Geociências, Universidade Federal do Rio Grande do Sul, Tese de Doutorado, $255 \mathrm{p}$. 
MILNE, G. 1934. Some suggested units of classification and mapping particularly for East African soils. Soil Research, 4(2): 183198.

MORALES, N. 2005. Neotectônica em ambiente intraplaca: exemplos da região sudeste do Brasil. Instituto de Geociências e Ciências Exatas, Universidade Estadual Paulista, Rio Claro, Tese de Livre Docência, 201 p.

OLIVEIRA, J.B; PRADO, H. 1989. Carta pedológica semi-detalhada do Estado de São Paulo: folha Piracicaba. São Paulo, IA - Instituto Agronômico / IGC - Instituto Geográfico e Cartográfico, escala 1:100 000.

PERROTTA, M.M.; SALVADOR, E.D.; LOPES, R.C.; D'AGOSTINO, L.Z.; PERUFFO, N.; GOMES, S.D.; SACHS, L.L.B.; MEIRA, V.T.; GARCIA, M.G.M.; LACERDA FILHO, J.V. 2005. Mapa Geológico do Estado de São Paulo, escala 1:750.000. Programa Geologia do Brasil - PGB, CPRM, São Paulo.

PINHEIRO, M.R. 2004. Fotopedologia da região do Pau D' Alho - Piracicaba / SP. A fotointerpretação como um instrumento no mapeamento de solos. Departamento de Geografia, Faculdade de Filosofia, Letras e Ciências Humanas, Universidade de São Paulo, Trabalho de Graduação Individual, $96 \mathrm{p}$.

PINHEIRO, M.R. 2014. Estudo morfotectônico da região da Serra de São Pedro e do Baixo Piracicaba/SP. Departamento de Geografia, Faculdade de Filosofia, Letras e Ciências Humanas, Universidade de São Paulo, São Paulo, Tese de Doutorado, 286 p. http:// dx.doi.org/10.11606/T.8.2014.tde-11052015170604

PINHEIRO, M.R.; QUEIROZ NETO, J.P. 2014. Reflexões sobre a gênese da Serra Geral e da Depressão Periférica Paulista: o exemplo da região da Serra de São Pedro e do baixo Piracicaba, SP. Revista do Instituto Geológico, 35(1): 47-59. http://dx.doi. org/10.5935/0100-929X.20140004

PINHEIRO, M.R.; QUEIROZ NETO, J.P. 2015. Neotectônica e evolução do relevo da região da Serra de São Pedro e do baixo Piracicaba/ Sudeste do Brasil. Revista Brasileira de
Geomorfologia, 16: 593-613. http://dx.doi. org/10.20502/rbg.v16i4.668

PINHEIRO, M.R.; QUEIROZ NETO, J.P. 2016. Geomorphology of the São Pedro ridge and Lower Piracicaba River region, southeastern Brazil. Journal of Maps, 12(1): 377-386. https://doi.org/10.1080/17445647.2016.122 7730

PINHEIRO, M.R.; QUEIROZ NETO, J.P. 2017. From the semiarid landscapes of southwestern USA to the wet tropical zone of southeastern Brazil: Reflections on the development of cuestas, pediments, and talus. Earth-Science Reviews, 172: 27-42. https:// doi.org/10.1016/j.earscirev.2017.07.005

QUEIROZ NETO, J.P. 2002. Análise estrutural da cobertura pedológica: uma experiência de ensino e pesquisa. Revista do Departamento de Geografia, 15: 77-90. https://doi. org/10.7154/RDG.2002.0015.0008

QUEIROZ NETO, J.P.; JOURNAUX, A. 1978. Carta geomorfológica de São Pedro, SP, Escala 1:50.000. Convênio Laboratório de Sedimentologia e Pedologia do Departamento de Geografia/FFLCH/USP/ Centre de Géomorphologie du CNRS - CAEN.

RICCOMINI, C. 1995. Tectonismo gerador e deformador dos depósitos sedimentares pós-gondvânicos da porção centro-oriental do Estado de São Paulo e áreas vizinhas. Instituto de Geociências, Universidade de São Paulo, São Paulo, Tese de Livre Docência, 100 p. https://doi.org/10.11606/T.44.2013. tde-03062013-103524

RICHTOFEN, F.F. von. 1886. Fürer für Forscungsreisende. Anleitung zu über Gegenstände der physischen Geographie und Geologie. Verlag R. Oppenheim, Berlin, 745 p. ("Guia para os exploradores. Instruções para observações diretas de objetos da geografia física e geologia").

SANTOS, H.G.; JACOMINE, P.K.T.; ANJOS, L.H.C.; OLIVEIRA, V.A.; LUMBRERAS, J.F.; COELHO, M.R.; ALMEIDA, J.A.; ARAUJO FILHO, J.C.; OLIVEIRA, J.B.; CUNHA, T.J.F. 2018. Sistema brasileiro de 
classificação de solos. Embrapa, Brasília, $5^{\text {a }}$ ed. rev. e ampl., 353 p.

SANTOS, R. D.; SANTOS, H. G.; KER, J.C.; ANJOS, L. H. C..; SHIMIZU, S. H. 2015. Manual de descrição e coleta de solo no campo. SBCS, Viçosa. $7^{\mathrm{a}}$.ed. rev. e ampl., $102 \mathrm{p}$.

SOUSA, M.O.L. 2002. Evolução tectônica dos Altos Estruturais de Pitanga, Artemis, Pau d'Alho e Jibóia-Centro do Estado de São Paulo. Instituto de Geociências e Ciências Exatas, Universidade Estadual Paulista, Rio Claro, Dissertação de Mestrado, 116 p.

TRICART, J. 1977. Ecodinâmica. FIBGE/ SUPREN, Rio de Janeiro, $91 \mathrm{p}$.
VILLELA, F.N.J.; ROSS, J.L.S., MANFREDINI, S. 2013. Relief-rock-soil relationship in the transition of Atlantic Plateau to Peripheral Depression, Sao Paulo, Brazil. Journal of Maps, 9(3): 343-352. https://doi.org/10.1080 /17445647.2013.805170

VILLELA, F.N.J.; PINHEIRO, M.R.; QUEIROZ NETO, J.P.; MANFREDINI, S.; ALVES, G.B.; BARREIROS, A.M.; NAKASHIMA, M.R.; SCIGLIANO, B. F.; MICHELON, C.R.; SANTOS, A.A.; SOARES, A.F.A.; BORSOI, H.R.G.; MELO, G.V.; SANTOS, R.F. 2018. Evolução do modelado de relevo e dos materiais no sopé da escarpa de Cuesta de São Pedro-SP. Revista de Geografia (Recife), 35: 131-144.

\section{Endereço dos autores:}

Marcos Roberto Pinheiro, Jéssica Rafaela Costa, Beatriz Ferraz Scigliano, Rosely Pacheco Dias Ferreira, Sidneide Manfredini - Laboratório de Pedologia do Departamento de Geografia, Faculdade de Filosofia, Letras e Ciências Humanas, Universidade de São Paulo, Avenida Lineu Prestes, 338, CEP 05508-080, Cidade Universitária, São Paulo, SP, Brasil.E-mails: m3279574@usp.br; jrcosta@usp.br; biascigliano@ gmail.com; rpfdias@usp.br; sidmanfredini@usp.br

Paola Cianfarra - Dipartimento di Scienze della Terra, Dell' ambiente e Della Vita - Università Degli Studi di Genova - Itália, Corso Europa 26, 16132 Genova, $1^{\circ}$ piano Palazzo delle Scienze, st. I-33, Itália. E-mail: paola.cianfarra@unige.it

Artigo recebido em 4 de setembro de 2019, aceito em 30 de outubro de 2019. 